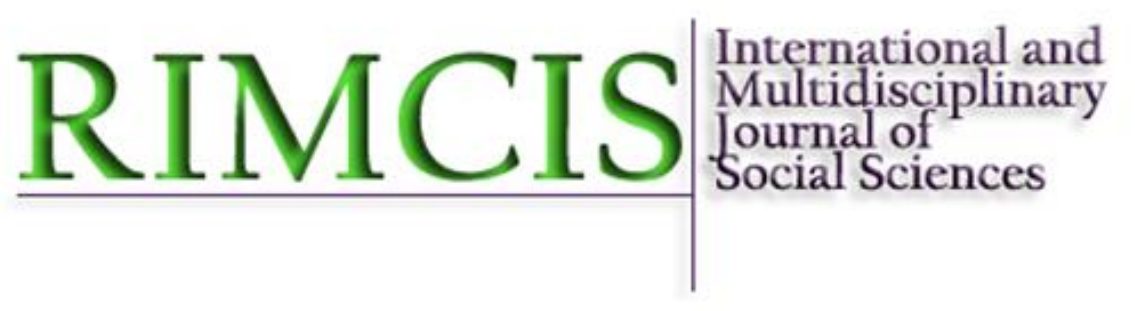

\title{
Volume 9, Number 1
}

\section{Hipatia Press \\ www.hipatiapress.com}

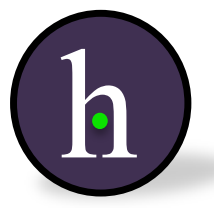

Untold Stories: A Study of Sudanese and Syrian Refugees in Estonia Aminul Islam.

Developmental Performance Ranking of SAARC Nations: An Application of TOPSIS Method of Multi-Criteria Decision Making Neeraj Narayan, Kaushalendra Kumar Singh, Ujjaval Srivastava.

Theorizing Beta Thalassemia Major: An Overview of Health Sociology Muhammad Abo ul Hassan Rashid, Saif-Ur-Rehman Saif Abbasi.........51

From Global North-South Divide to Sustainability: Shifting Policy Frameworks for International Development and Education - Shalini Singh.....

Book review: Anna Odrowąż-Coates, Sribas Goswami (Eds.) (2017). Symbolic violence in socio-educational contexts. A post-colonial critique. Warsaw: Wydawnictwo Akademii Pedagogiki Specjalnej im. Marii Grzegorzewskiej - Iwona Nowakowska. 


\section{Untold Stories: A Study of Sudanese and Syrian Refugees in Estonia}

Aminul Islam

Tallinn University

\section{Abstract}

The aim of this study was to explore the coping resources and the present and past experiences of two groups with refugee experiences in Estonia through narrative approach. Avert narratives, Struggling narratives, Instantaneous narratives, Boundary narratives, and Re-occurrence narratives identified through the interviews with 12 refugees. Differences between this two groups and individual accounts were also identified. The structure of the narratives, identity construction while in exile and coping mechanism through the narratives shaped their life stories and lives in exile. One significant outcome of this study is the lack of compatibility of the stories between two groups, through which five narratives established to elaborate the variety of their accounts.

Keywords: refugee, Estonia, narrative, memory, story 


\section{Historias No Contadas: Estudio de Refugiados Sirios y Sudaneses en Estonia}

Aminul Islam

Tallinn University

\section{Resumen}

El objetivo de este estudio fue explorar los recursos de afrontamiento y las experiencias presentes y pasadas de dos grupos con experiencias de refugiados en Estonia a través del enfoque narrativo. Las narrativas de evitación, las narrativas de lucha, las narrativas instantáneas, las narrativas de límites y las narrativas de reaparición identificadas a través de las entrevistas a doce refugiados. También se identificaron las diferencias entre estos dos grupos y los testimonios individuales. La estructura de las narrativas, la construcción de la identidad en el exilio y el mecanismo de afrontamiento a través de las narraciones moldearon sus historias de vida y sus vidas en el exilio. Un resultado significativo de este estudio es la falta de compatibilidad de las historias entre dos grupos, a través de las cuales se establecieron cinco narrativas para elaborar la variedad de sus relatos.

Palabras clave: refugiados, Estonia, narrativa, memoria, historia 


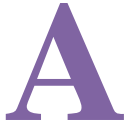

ccording to Teski and Climo (1995) storytelling belongs to those activities that makes us human. Told stories often become the changes that occur over a period of time. How we construct our identity is complex phenomenon and never happens in isolation, but it is a process which can be called interactive and directed towards the stories told by the participants for a large audience (Goffman, 2002). It does not mean that people's identities are not authentic, rather it gives the plural and vocal nature of identity which has influence of the individual's or the narrator's past, present and future through their social, cultural, historical, family or political aspects (Feuchtwang, 2003).

Riessman in the year 2008 in his study of refugee stories stated that when people tell their stories of their lives, they actually live with those stories what they tell. Any disruptions of life, which leads separation from family members and be associated with force migration and then the ultimate result is the loss of country and home. To cope with the new environments and to reconstruct identity, stories that the refugees hold and to give them the space of telling that could assist them in creating new identities in terms of home and host society and culture and to gain control of their new lives in a foreign land (Leydesdorff, 2000; Frank, 2010).

However, many studies on the other hand pointed out that traumatic experiences could interfere memories, which could lead the refugees preventing to associate memories, which could make them unable to adapt new experiences (Keyes \& Kane, 2004; Obrist \& Buchi, 2008; Weingarten, 2003). Stories related to traumatic memories are not pleasant and sometimes people try to suppress these unpleasant memories, their thoughts and actions related to traumatic experiences (Herman, 2001) and if they share their experiences negatively and it makes effect to their identity or their any wellbeing, then to avoid or suppress their stories gets validated (Anderson et al., 2010). However, Herman (2001) pointed out that retelling and revising stories help people to organize and integrate their fragmented experiences or memories, which could create new coherent narratives and ultimate helps to get rid of post-traumatic experiences. This way, people could select their past as memory which is very dynamic in everybody's mind, filter them and then restructure them in terms of present situation and future needs. This 
process also creates an environment to create counter narratives to heal them from the experiences, at the same time keeping the values of their self and family. Counter narrative can be defined in a way which challenges the dominant view of a given society, as often refugees are viewed as traumatized people and can be burden for the society (Herman, 2001).

\section{Memory and Narrative}

Participants memory plays important role to build narratives (Halbwachs, 1980). It is often considered that memories reflect one's self reflection, but also has social aspects in it (Bneezer, 2002). It is often highlighted that refugees should forget their past to be able to cope with their new societies, hence instead of past memories, it is expected that refugees should focus on the new memories (Teski \& Climo, 1995). In this regard it is important for researchers and social scientists to pay attention to memories that are not being heard. If untold memories are acknowledged, researchers would be able to come up with new ideas to address refugee issues (Feuchtwang, 2003).

Language play significant role in sharing memories, through which their past images comes into social construction (Leydesdorff, 2000). The link between language and memories has been emphasized by the researchers (Alexander, 1995) to reflect refugee lives. Metaphors that come through language reflects their stories and play important role to illustrate refugees daily life (Burner, 1987). Self identity can be recognized through shared language and thoughts (Linde, 1987)

It is believed that cultural symbols can be addressed through shared language and narratives through which refugee's past and present can be analyzed (Cavarero, 2000). Often told narratives expressed by an individual is viewed as complete personal aspect but the path it came through, the sense of vibration it creates, the language being used gives us the cultural narratives of which any individual is exposed (Bneezer, 2002).

Social class can also be found and analyzed by the narratives told by the participants (Tonkin, 1992) and it usually depends on the selections of the plots and themes and which way we want to recall their lives and memories. George Steinmetz (1992) for instance stated that themes that are the creation 
of told stories through language are actually the reflection of culture, gender or race. To be able to acknowledge their sense of identity, told narratives play vital role and is significant to know the any society where we live. (Dawson, 1994) It is not that all the told stories help to understand the culture but the sequential path that it follows and its life cycle gives us the plot to understand it (Andrews, 2004). Tonkin (1992) in a study on Jlao community in Liberia stated that same stories can have several meanings, therefore it is important to understand the plot to be able to illustrate the complete situation. Gleason (1983) stated that our self-hood is a reflection of the society where we belong and its values. Our memory this way becomes the major source of our identity and then the changes that we make in our life are the the narratives from within a story being told.

\section{Migration and Memory}

Sense of belonging and the space they belong is very significant for migrants and it comes from the memory that they carry and their imagination (Constance, 2004). For transnational families, narratives play vital role to form their identity (Appadurai, 1996), which can reflect how they adapt in a new society. In a study on Christian refugees, Bryceson and Vuroela (2002) figured how gender and status of migrant can play different role in sharing memories. The role of male and female can also be changed in a different context as Thompson and Bauer (2005) pointed out that the role of a migrant father was changed in a different country context and was explained completely different way while telling stories.

Family dynamics can be presented through oral stories. In a study on African Caribbean families, Constance (2004) pointed out that family reunion and constant communication with family members back home is significant for migrant families which provide them the sense of belonging and also identity practice. It is often viewed that knowing family is knowing themselves and shared memories play a significant part in it. Shared life stories provide an individual to express the sense of emotion which in turn could help in adapting a new society (Nussbaum, 2001). 


\section{Context of Estonia}

Estonia recently transformed from a refugee producing country to a refugee hosting country (Tammaru et al., 2010). The number of applicants started to increase in the year 2010 but reached at its peak in the year 2015, when the number of asylum seekers were 230. However, by the end of 2018, there were 322 refugees living in Estonian (UNHCR, 2018). Estonia also agreed to accept quota refugees as part of European relocation program and these refugees are from Non- European ethnic background. Islam (2016) in his study on Estonian refugees, pointed out that there is no significant academic research on existing refugees from outside Europe, Estonia will start to receive quota refugees from non-European ethnic background. Therefore, academics and researchers need to address this issue to integrate these refugees into the host society.

\section{Aim of This Study}

Any groups or community in a society, which are marginalized need to have adequate space, so they can tell their stories at a pace which can be conducive for them. Researchers duty is to move beyond the words and to extract the silences and blank untold stories (Sorsoli, 2010). To explore silences and untold stories, unstructured life story method is suitable for the researchers, as it allows bringing out the counter narratives through long conversations, which allows the narrators to reveal their stories (Ward, 2003).

Spector-Mersel (2011) proposed a narrative interpretive model to find out the identity of the narrators and according to him it can be revealed by the Narratives end point (EP), researchers need to attend or focus on what is added in the stories and what is excluded. To be able to come up with the end point (EP), one needs to take the silences (what is excluded), omissions (were irrelevant), and flattening (were told but not elaborated) into account to reconstruct identity, which can be suitable for themselves.

By studying specific settings, this study aimed to explore the coping resources and the present and past experiences of two groups with refugee experiences in Estonia through narrative approach. 


\section{Methodology}

\section{Participants}

Participants having refugee status were from Syria (seven) and Sudan (five) and they are living in Estonia. Among the participants, eight were men and four women aged between 21 and 57 years. Participants from Sudan's average age was 34 and Syrian participant's average was 36 years. There was not any feasible difference between these participants on the basis of age or how many years they are in Estonia. To ensure the confidentiality of the participants, their individual particularities will not be provided.

To gain the access of the participants, contact was established with the support person, who provides various support to resettle refugees in Estonia. Once the contact was made, some participants referred their friends who they believed will be willing to share their stories.

Participants were well-informed about the research the perspectives of this study. Participants gave the consent to audio-taping. However, as this study was carried out in a refugee center, according to the center's rules and regulations, I was not allowed to carry any audio-taping out of the center. So, I had to transcribe the data before I left the center. Participants from Sudan was more heterogeneous, in terms of religion and education, two of them had university degree and three of them are Christian and two Muslim, whereas participants from Syria are all Muslim and there were no one who had university degree. However, all participants were educated and had good level of English, when it comes to communicate.

\section{Data collection}

Open ended face to face interviews were carried out between December 2016 and March 2017 at Vao Keskus. This is the place where asylum seekers and refugees are placed in Estonia. However, they were asked to choose their preferred venue, so they feel comfort to express their stories, and they preferred to have it where they live. Interviews were mostly done in about one hour to three hours session. Their life stories were collected through unstructured interviews, starting with an opening statement and then 
follow up questions for clarifications to enhance understanding. All interviews begun with the statement: Please tell me your life story in your way. You can start with your life back your home country and then continue your stories as your journey continued till Estonia, your first experiences in Estonia and the later time and what you frame for future life.

\section{Data Analysis}

To analyze the stories, a case-centered narrative approach was used (Riessman, 2008). Interviews were transcribed and checked carefully. Next step was to describe interviews thematically, this way a structural element of narratives identified to get the main points of the stories and overall context of the study-who, when and where; to evaluate the emotional perspectives of the narrator (Labov, 2008) The aim of the analysis was to present the holistic interpretation of each told story which included individual, socio-cultural, interpersonal influences (Josselson, 2011). Any ambiguities that arose of this study were discussed with the participants. However, respondents' names and any aspects that might reveal their circumstances were omitted to preserve their confidentiality.

\section{Analysis}

Participants of this study were asked to tell their story in their words to feel comfort while sharing. Participants from Sudan explained their stories in an order and stories were equally distributed while described their life in Sudan and then exile time to Estonia. Their stories contained powerful feelings and clear image of their events and experiences that they have gone through in different stages. Stories from Syrian refugees on the other hand were not told systematically when it came to share their stories in their country of origin to the country where they are relocated now. Most of their stories were not concentrated on their homeland, concerning conflicts and war related experiences. However, follow up questions drove them to gain momentum and to express their stories on conflicts and war situation.

Considering this variance within this two groups, some individual were also identified concerning the structure of the respondent's narrative and 
accordingly five narratives emerged through told stories: avert narratives, Struggling narratives, Instantaneous narratives, Boundary narratives, and reoccurrence narratives.These narratives have been emerged by using Grounded theory as it provides flexible guidelines to explore and analyze data (Thornberg \& Charmaz, 2014).

\section{Avert Narratives: 'I am from Syria and then I moved to live in Turkey'}

Syrian narratives had small accounts of their home land and war related experiences. Syrian narratives were reluctant to elaborate their conflict related experiences, it can be the reason that they want to avoid these stories, which can affect their mental well-being. Sayeed, a 32 years Syrian, left his country when he was 29 , he described his story of his life in his home country shortly:

\section{Extract 1}

1. I was living in Syria with my family and friends

2. Conflict begun in Syria

3. Then I was forced to go abroad

4. It was not for holidays, only to find myself in a refugee camp

This respondent described his life in his country of origin in few sentences $(1.1,1.2)$, hence the narratives of his home country and war related story has not been well formulated. Family and friends however has been a hint (1.1), which can be extracted in regard to life at home. War related story plot can be elaborated in relation to the consequences of forced migration (1.4) and it was not for any amusement or holidays, but no elaboration of the experiences is formed. On the other hand, when explained the life in Estonia, many descriptions are offered as from Extract 2.

\section{Extract 2}

1. Initial period was difficult for many reasons...

2. I do not know local language.

3. I have no friends and relatives...

4. I cannot share anything with anybody, no help from anybody. 
5. No one talks here, so cold and dark...

6. I do not see any people on the street, culture is different.

7. It is completely a different country.

Respondent in this extract shared his difficulties and described it clearly $(2.1,2.2,2.3,2.4,2.5,2.6)$ in contrast to the first Extract. Language problem and not having family members and friends (2.1 and 2.3) to share his struggle can be understood. Climate differences and cultural barrier is mentioned clearly (2.5 and 2.6) and while it was shared, way of expressing the stress was clearly evident. His experiences in Estonian was clearly described and later his thoughts about future in Estonia was also well described in contrast to the narratives in Homeland.

Sayeed, time to time went back to share his thoughts on how his life was back home in regard to life before war and how nice it was to compare life that he is leading abroad but then his comments on life back home was very brief with almost no detail description to evaluate his thoughts and was not offered to narrativize his life during the and after the war.

Other respondents from Syria were likewise reluctant to share their narratives of war. They shortly described where they are from and then proceeded their life in exile as Rafal a 27-year man described 'I was 24 when I left Syria and then from there, I moved to Turkey to Europe.' Even while asked to describe their story at home, the account was brief as follow:

\section{Extract 3}

1. Can you remember your stories in the war period and the journey that you had till Estonia?

2. Yes, I can remember very well.

3 . Could you share your stories?

4. I had to spend money to leave and to reach Europe and the brokers took all before I reached to Europe and when I was sent to Estonia, I had nothing that I took from home.

5. I am still lucky I made it here. It was a horrible journey.

Rafal came to Estonia, and he had to spend more than three thousand euro to cross the sea to reach Europe in the first place. Here it is again 
evident that no description was provided in regard to life in Syria and war narratives. Journey towards Estonia is described (3.4) as he mentioned it was 'horrible' but any description of horrible experiences is mentioned other than 'they took away all.' However, most of the Syrian refugees described their challenges of their initial period being exile and their hopes for the future, it can be extracted from this Extract (3.5) as he mentioned 'I am lucky I am alive and made it here', which shows her desire to life and to focus on her future life.

\section{Tussle Narratives: 'Everything was gone in a moment...people died, screamed around'}

Since the Syrian Narratives of their life back home was almost non-existent, some follow up questions were utilized to elaborate their description but at the same time participant's willingness to express their own narrative was respected. In doing that so, nonverbal expressions have been taken into account. It is also understood that sometimes refugees try to avoid their distressing experiences and often think of their pleasant life before the conflict or before war begun as their coping device to go forward. Some studies have focused on how refugees made their effort to forget their previous memories and to concentrate on their current situation and to keep up their hope for the future. Children future, education and safety and successful life made them optimistic to adapt elder generation into a new societal context and at the same time think of their homeland before war (Hoot, 2011; Roxas, 2011; Este \& Tachble, 2009). This particular aspect is also supported by the interviews with the Sudanese. However, Syrian narratives differ from this pattern, as illustrated below:

\section{Extract 4}

1. Can you tell me your life in Syria?

2. Sure...

3. Life was so good but then the war......people screaming, dying, and things that I never saw before...

4. What about your life before conflict broke? 


\section{Aminul Islam - Refugees and Untold Stories}

5. I had my parents, they had good job.... I had my brothers, they were studying...

6. They all died, only I survived...

7. I went to the refugee camp in Turkey all alone and it was difficult....

Rafal's war related narratives are not yet developed from this extract, possibly it was because he became too emotional to express. He informed his family member's death (4.6) but did not elaborate how it all happened. He described the event, but he did not explain the circumstances behind and surrounding that. His emotion of losing all family members and how he spent time afterwards and what are the 'difficulties' was not elaborated. At the same time, it is to state that the nonverbal expression conveyed his emotion. Rafal's narratives slowly got into exile as he mentioned 'only I survived' (4.6) despite the fact that in the Extract 3 he mentioned 'I am lucky that I made it' but his narrative in this extract elaborated his difficulties in the camp and the journey being all alone. There is significant difference of narrative structure-willingness to narrate Syrian narratives are not wellformed, whereas narratives of exile are well-formed.

\section{Instantaneous Narrative: 'It is a never-ending story'}

Zara's narrative a 21-year Syrian girl can be considered as an exception. She also started her story quickly going through life in Syria in saying one or two sentences, ending her remark 'what else!' When prompted by the interviewer to describe her childhood by utilizing the same technique as Rafal's case, she changed her mood into a nostalgic account of how she spent her childhood with family and friends, which then moved to her feelings and thoughts to make it a well-developed narrative:

\section{Extract 5}

1. I left Syria 4 years before when it was impossible to live ...

2. What else!

3. What about your childhood in Syria?

4. Life was peaceful and good.

5. Anything else that you can remember? 
6. We were living like a free bird

7. I had my family, friends, relatives

8. I could visit to my neighbours family

9. Many events around to have fun with others

10. I grew up in a friendly environment.

11. Everything was great.

The progression is somewhat similar to Rafal's narrative which drove to the war and conflict situation in the next extract on conflict life chaos and tough experiences.

\section{Extract 6}

1. Then the conflict started

2. Then war broke out...

3. Trying to look for shelter

4. You don't know where you are heading

5. Can you remember?

6. Yes, I can.... sometimes it just comes and go...all the scenes ...

7. When I close my eyes off.... it's like watching a video

8. People running around....

9. Screaming, and I could have been killed

10. It is a never-ending story......

Zara's account of Syrian war is short, when prompted by the interviewers to elaborate she switched to a mode to express how it how she feels on her stress experiences by saying 'Yes, I can, sometimes it just comes and go. '(6, 6) She finally attempted to describe war related narrative by expressing (6.8, 6.9), it was however not a fluent elaboration. When she was asked- 'can you remember', she said- Yes, I can, then she described how she feels (6.7) instead of describing what she recalled. Finally, her war related story moved to a point of fear narrative (6.9) and then she quickly returned to the present narrative as she mentioned, it is a never-ending story (6.10), instead of elaborating her never ending narrative, she moved to narrate her present situation. 


\section{Aminul Islam - Refugees and Untold Stories}

\section{Boundary Narrative: 'I do not want to share details about it now'}

Despite the fact that the participants from Sudan expressed their war related traumatic events very organized way in detailing what they witnessed, yet they expressed a point of disclosure to get into detail, so they do not feel distressed. Awchake a 35- year man expressed his narrative

\section{Extract 7}

1. I am Awchake.... my stories during the conflict period that lived my life....

2. I don't know whether it was war or conflict, but it was horrible. I may not be able to provide all information ...

3. However, I will try to recall the basics with sequence

4. But I do not want to provide details as I will feel stress out later then.

Awchake has expressed his stories in the war period with an afford to make it descriptive narrative by explaining his experiences of traumatic events, how he was tortured, female members being raped, fear of abduction, he even expressed that he witnessed killings, homes being burned, how chaos broke out, people looting even from neighbour's home. In order to validate his account, he even revealed some of the marks of him being tortured. It is a detailed war related narrative of which he tried to orient his audience. He ended up his Sudanese narrative by stating how he escaped and fled to the neighbour country and for that he is thankful to his God. Awchake's homeland narratives can be intertwined by his religious beliefs as he stated God help many times. His statement of not to get into details (7.5) can be elaborated with the fact of protecting himself and to avoid potential invasive questions or interruptions which actually in turn prompted to form his own narratives. 


\section{Re-occurrence/coming-going back Narratives: I keep on thinking people are being killed, houses are burnt.}

Sudanese narratives on their trauma experiences expressed repeatedly, sometimes because of the question that the interviewer asked and sometimes it came spontaneously to describe their homeland narratives. Reagan who was 29, when he left Sudan described how he lost his home, when rebellion came and destroyed his house and killed his parents, he survived and ran away without knowing where he was heading and the fortune of his other family members. He fled to a refugee camp and finally reached to Estonia. While explaining his post migration narrative, he went back to describe his stories of how he escaped Sudan:

\section{Extract 8}

1. I have no one here.

2. I don't even know what happen to my other family members

3. I keep on thinking people are being killed, houses are burnt...

4. Dead bodies around....and you walk through them...

5. These memories will never die out from my mind...

Reagan started with his account of his present life and his feeling of being alone (8.1) and to have some of his loved ones around, when he doesn't know what happened to them (8.2). Then he proceeded to return to his homeland narratives by describing his account of traumatic event (8.3, 8.4), even though it is not totally well-formed narrative but the illustration of his traumatic experiences are expressed through 'you walk through them.' As one of the aims of this study was to explore the coping mechanism, hence Reagan was asked how he went past these experiences, Reagan described about his mental state of affairs in relation to his experiences with the consultant.

\section{Extract 9}

1. I don't really think counselling works...

2. Some questions, I do not want to answer 
3. Sometimes I found it strange when she asked questions which I do not want to deal with

4. They keep me back to the home memories...

5. You do not want to keep saying how you could have been slaughtered

6. So, I did not continue...

His account of counselling was on a negative note (9.1, 9.2, 9.3, 9.5, 9.6) while asked about counselling and how it helped in coping, he again returned to his conflict related narrative. This extract also provides the fact that lack of proper psychological counselling which is needed to apply for particular group of people.

At the end of this long interview, when asked about his religious belief and how it helped in coping during his exile period, Reagan progressed very organized way and his description came spontaneously. He described how it makes a sense of his life to go forward throughout his journey from war to exile:

\section{Extract 10}

1. We pray, because that gives us some kind of hope.

2. When houses are burnt, people are being killed, you still pray

3. You don't know whether you will make it...

4. I am a Christian, so I know God has a purpose to send me...

5. There should be a meaning of life...

6. So, I am not going to give up. I will keep on running...

Sudanese account of religious belief helped them to look forward, many times their description took them to return repeatedly of their homeland narratives (10.2). In the end of the long interview with the participants from Sudan, many of them expressed that they never shared their stories with anybody, and their stories have never been told. Regan for instance said- he never had the chance to share his stories related to trauma with his own community people, as they all have their own stories, so he never wanted to give them something extra, which can again affect them to recall their tough memories. 
Elori a 23 years Sudanese girl for instance expressed her detailed narrative on how she fled her country, her school days back home, and friends, her studies in Estonia and future thoughts. She elaborated the event when she lost her only brother while in exile. Elori's narrative ended with following:

\section{Extract 11}

1. My brother was the only member from my family who I can share things...

2. I had nothing to do, just to observe my brother passed away...

3. There was no funeral, we just buried him...

4. Then I realized, I have lost...

5. I think this is the first time I am talking about my brother...

Interview with Elori conveyed how she felt when she lost her brother and the shock 'I have lost.' $(11.1,11.2,11.3,11.4)$ Her fragmented sentences indicates the emotion narrative. She one point mentioned 'sorry for being emotional' indicates that she did not want to express her emotion but as she mentioned 'I think this is the first time I am talking about my brother' indicates she was overwhelmed by the event and her account of loneliness can be observed.

\section{Discussion}

Interviews with the respondents produced five narratives of Avert narratives, struggling narratives, Instantaneous narratives, Boundary narratives, and Reoccurrence narratives. Participants were more fluent in elaborating their narratives of exile, life in Estonia than expressing their homeland and war narratives. Syrian participants were more reluctant in expressing their stories on war and conflict, whereas Sudanese narratives were more descriptive and elaborative.

Avert narratives were dominated by the accounts of Syrian participants who were silent in expressing their war related experiences. However, participants from both Sudan and Syria struggled to share their elaborate experiences of conflict related stories, which is however somewhat related to 
the fact that it can impact negatively of their trauma narratives (Bneezer, 2002). Syrian narratives appeared more segmented than Sudanese narratives as it appeared that Syrian quickly mentioned their homeland narratives in one or two sentences and then moved to the next narratives on life in Estonia. Sudanese narratives appeared more organized and elaborated starting from homeland to exile but at the same time it appeared boundary line narratives in elaborating trauma related experiences. War related narratives still appeared less described but was more elaborated when prompted by the interviewer.

Religious and spiritual aspects appeared a measure of adaptation while in exile or difficult situation. Sudanese narratives appeared very strong in spiritual aspects as one respondent mentioned 'I am a Christian, so I know God has a purpose to send me', which can also be supported by the other studies. Religion is quite close to cultural aspect, thus create a guide of feelings, thoughts and somewhat associated with identity. It might sound as an individual coping strategy when it comes to religious beliefs but can be associated with societal and cultural aspects (Park \& Aii, 2006). Participating religious activities can be associated with good mental health but on the other hand those faced persecution based on religion, in many instances it is not as good as for other groups. Sudanese refugees in Germany for instance prayed intensively for their country's situations to improve (Schweitzer et al., 2007). Khawaja and his colleagues did research on South Asian refugees in Australia, and he figured that during the transit, refugees always pray to get things better and to have changed their current situation and this way they found moments of peace. Many studies focused on refugees' life and their experience through religion and beliefs. Tibetan refugees in India make their presence by focusing both past and present life through religious practice and beliefs through Dalai Lama and Buddhism (Hussain \& Bhusan, 2013). Some Sudanese refugees for instance in Norway took their extreme traumatic situation as God will make them to heal that in future things will get better (Goodman, 2004).

Returning narratives appeared from both group of participants, and they keep focusing on family and friends. Loneliness and being all alone also somewhat preventing in coping with ne new environment while in exile. Aspects of community and family have been focused from the previous 
studies as part of coping mechanism as well. Children with their parents and other family members have sound mental health than those who arrived alone, stated by Fazel and his colleagues (2012), this study also stated that in the family environment those who discussed the conflict and war situations on their home countries have the chances to have children with mental issues than those who avoided discussing these previous incidences.

Support from social services, a family with extended members and community can function as to perform better and to resettle refugees into a new country context (Lim, 2009; East et al., 2010). Family reunion can be a matter of coping strategies, and they give the support both in mental and materiel context. In a study of refugees in Australia, Wilmsen (2013) presented many aspects that are negatively correlated while a refugee or a group of refugees are separated from their family members.

Family ties are also important as many studies also highlighted its importance. Intergenerational ties for instance has been described by Lewis (2010) in his study on Cambodian refugees to focus on how they became resilient to getting over societal and cultural gaps between the society that they are currently based in and their home country context.

Not having the chance to share experiences was mentioned by the participants. Sharing experiences, emotion among the family members have been highlighted by a study on refugees in Canada (Simich et al., 2014). Tamil refugees for instance in Norway were proactive in reducing future stress and to manage any strange situations by taking collective action (Guribye et al., 2011) Research on how refugees face their traumatic situation also highlighted on family ties and collective action. For instance, a study on Tamil refugees in Norway, Guribye et al. (2011) also described that refugees tried to absorb and heal any news in relation to deteriorating situation and more conflict in their country of origin. In a study of refugee women in Sweden, Boerema and her colleagues (2010) stated that weeding participation, wearing traditional dresses and enjoying parties in traditional ways and music also helps in settling a new society. 


\section{Conclusion}

In order to understand refugee families and how they adapt in a new society, memory and narratives play vital role in constructing 'their self' as Halbwachs (1980) in his study on refugees and their adaptation came up with the statement that it is important to focus on the participants memory and its significance to construct their narratives. Memories can be viewed as individual aspect; however, it has the importance of the social aspect as well (Teski \& Climbo, 1995). It is expected that refugees should cope with their host societies values and norm, in this process memories of past somewhat relegate and their present memories become more dominant (Bneezer, 2002). This study explored to address those memories and stories that have not been heard or listened, in order to come up with new narratives. Participants were really happy of sharing their experiences as it appeared the first time whom they could share their struggle during the war period and in exile. However, one significant outcome of this study is the lack of compatibility of the stories between two groups, through which five narratives established to elaborate the variety of their accounts. Concerning the coping mechanism and identity construction, different ways are identified from their narratives. From a collective point of view these narratives will enhance our understating of the refugee communities in Estonia and their ways of solving problem and coping mechanism.

\section{References}

Alexander, S. (1995). Becoming a woman. Verso.

Anderson, J. M., Reimer, J., Khan, K. B., Simich, L., Neufeld, A., Stewart, M., \& Makwarimba, E. (2010). Narratives of "dissonance" and "repositioning" through the lens of critical humanism: exploring the influences on immigrants' and refugees' health and well being. Advances in Nursing $\quad$ Science, 33(2), 101-112.

http://doi.org/10.1097/ANS.0b013e3181dbc56b

Andrews, M. (2004). Narrative Research. In C. D. Seale, J. Silverman \& G. Gobo (Eds.), Qualitative Research Practice (pp. 109-124). Sage. 
Appadurai, A. (1996). Modernity at large: cultural dimensions of globalization. University of Minnesota Press.

Berger, R. (2013). Now I see it, now I don't: Researchers position and Reflexivity in Qualitative research. Qualitative Research, 15(2), 1-16. http://doi.org/10.1177/1468794112468475

Boerema, C., Russell, M., \& Aguilar, A. (2010). Sewing in the lives of immigrant women. Journal of Occupational Science, 17(2), 78-84. http://doi.org/10.1080/14427591.2010.9686678

Bneezer, G. (2002). The Ethiopian Jewish exodus: narratives of the migration journey to Israel 1977-1985. Routledge.

Bruner, J. (1987). Life as narrative. Social Research, 54, 11-32.

Bryceson, D., \& Vuorela, U. (2002). The transnational family: new European frontiers and global networks. Berg.

Cavarero, A. (2000). Relating narratives: story telling and selfhood. Routledge.

Constance, R. S. (2004). Celebrating Ourselves: The Family Reunion Rituals of African-Caribbean Transnational Families. Journal of Transnational Affairs, 4(3), 243-257. http://doi.org/10.1111/j.1471-0374.2004.00091.x

Crossley, M. L. (2000). Narrative psychology, trauma and the study of self/identity. Theory and Psychology, 10, 527-546. http://doi.org/10.1177/0959354300104005

Dawson, G. (1994). Soldier heroes: British adventure, empire and the imagining of masculinities. Routledge.

East, L., Jackson, D., O’Brien, L., \& Peters, K. (2010). Storytelling: An approach that can help to develop resilience. Nurse Researcher, 17(3), 17-25. http://doi.org/10.7748/nr2010.04.17.3.17.c7742

Este, D. C., \& Tachble, A. (2009). Fatherhood in the Canadian context: Perceptions and experiences of Sudanese refugee men. Sex Roles, 60(78), 456-466. http://doi.org/10.1080/1754730X.2012.664858

Fazel, M., Reed, R. V., Panter-Brick, C., \& Stein, A. (2012). Mental health of displaced and refugee children resettled in high-income countries: Risk and protective factors. The Lancet, 379(9812), 266-282. http://doi.org/10.1016/S0140-6736(11)60051-2

Feuchtwang, S. (2003). Loss: transmissions, recognitions, authorisations. In S. Radstone \& K. Hodgkin, Regimes of memory (pp. 76-90). Routledge. 
Frank, A. W. (2010). The Wounded Storyteller: Body, Illness, and Ethics. University of Chicago Press.

George, S. (1992). Reflections on the Role of Social Narratives in WorkingClass Formation: Narrative Theory in the Social Sciences. Social Science History, 16(3), 489-516. http://doi.org/10.1017/S014555320001659X

Goffman, E. (2002). The Presentation of Self in Everyday Life. Doubleday. Goodman, J. H. (2004). Coping with trauma and hardship among unaccompanied refugee youths from Sudan. Qualitative Health Research, 14(9), 1177-1196. http://doi.org/10.1177/1049732304265923

Gleason, P. (1983). Identifying identity: a semantic history. Journal of American History, 69, 910-932. http://doi.org/10.2307/1901196

Guribye, E., Sandal, G. M., \& Oppedal, B. (2011). Communal proactive coping strategiesamong Tamil refugees in Norway: A case study in a naturalistic setting. International Journal of Mental Health Systems, 5(9), 1-13. http://doi.org/10.1186/1752-4458-5-9

Halbwachs, M. (1980). On collective memory. Harper \& Row.

Herman, J. L. (2001). Trauma and Recovery: From Domestic Abuse to Political Terror. Pandora.

Hoot, J. (2011). Working with very young refugee children in our schools: Implications for the world's teachers. Procedia Social and Behavioral Sciences, 1751- 1755. http://doi.org/10.1016/j.sbspro.2011.03.363

Hussain, D., \& Bhushan, B. (2013). Posttraumatic growth experiences among Tibetan refugees: A qualitative investigation. Qualitative Research in Psychology, 10(2), 204-216. http://doi.org/10.1080/14780887.2011.616623

Islam, A. (2016). Refugee Quota: Is Estonia Ready to Receive Refugees? A Review of the literature Migration and Ethnic Minorities in Estonia. International Multidisciplinary Journal of Social Sciences, 5(3), 281-297. http://doi.org/10.17583/rimcis.2016.2225

Josselson, R. (2011). Narrative Research Constructing, Deconstructing and Reconstructing Story. In F. J. Wertz, K. Charmaz, L. M. McMullen, R. Josselson, R. Anderson \& E. McSpadden (Eds), Five Ways of Doing Qualitative Analysis (pp. 224-242). Guildford Press. 
Kacen, L., \& Chaitin, J. (2006). The times are a changing: understanding qualitative research in ambiguous, conflictual and changing contexts. Qualitative Report, 11, 209-228.

Keyes, E. F., \& Kane, C. F. (2004). Belonging and adapting: Mental health of Bosnian refugees living in the United States. Issues in Mental Health Nursing, 25(8), 809-831. http://doi.org/10.1080/01612840490506392 Labov, W. (2008). Oral Narratives of Personal Experience. In Cambridge Encyclopedia of the Language Sciences. Cambridge University Press.

Lewis, D. C. (2010). Cambodian refugee families in the United States: "Bending the tree" to fit the environment. Journal of Intergenerational Relationships, 8(1), 5-20. http://doi.org/10.1080/15350770903520635

Leydesdorff, S. (2000). Gender and the categories of experienced history in D. Davidoff, K. McClelland \& E. Varakis (Eds.), Gender and history: retrospect and prospect (pp. 179-194). Blackwell Publishers.

Lim, S.-L. (2009). Loss of connections is death: Transnational family ties among Sudanese refugee families resettling in the United States. Journal of Cross-cultural Psychology, 40(6), 1028-1040. http://doi.org/10.1177/0022022109346955

Linde, C. (1987). Explanatory systems in oral life stories. In D. Holland \& N. Quinn (Eds.), Cultural models in language and thought (pp. 343-366). Cambridge University Press.

Lucky, R., David, G., \& James, O. (2015). Syria: The story of the conflict. BBC News.

Nussbaum, M. C. (2001). Upheavals of thought, the intelligence of emotions. Cambridge University Press.

Obrist, B., \& Büchi, S. (2008). Stress as an idiom for resilience: Health and migration among sub-Saharan Africans in Switzerland. Anthropology and Medicine, 15(3), 251-261. http://doi.org/10.1080/13648470802357596

Park, C. L., \& Ai, A. L. (2006). Meaning making and growth: New directions for research on survivors of trauma. Journal of Loss and Trauma, 11(5), 389-407. http://doi.org/10.1080/15325020600685295

Passerini, L. (2003). Memories between silence and oblivion. In K. Hodgkin \& S. Radstone (Eds.), Contested pasts: the politics of memory (pp. 238254). Routledge. http://doi.org/10.4324/9780203785751 
Richie, B. (1995). Racism, ethnic stigma and gender violence: exploring the intersections of oppression. Plenary Midwest Conference on Child Abuse and Incest, University of Wisconsin, Madison, WI, 9 November.

Riessman, C. K. (2008). Narrative Methods for the Human Sciences. Sage Publications.

Roxas, K. C. (2011). Creating Communities: Working with Refugee Students in Classrooms. Democracy and Education, 19(2). http://doi.org/10.7748/nop.27.1.41.s22

Schweitzer, R., Greenslade, J., \& Kagee, A. (2007). Coping and resilience in refugees from the Sudan: A narrative account. Australian and New Zealand Journal of Psychiatry, 41(3), 282-288. http://doi.org/10.1080/00048670601172780

Simich, L. (2014). Editor's introduction. In L. Simich \& L. Andermann (Eds.), Refuge and resilience (pp. 1-6). Springer Netherlands.

Sorsoli, L. (2010). Echoes of Silence: Remembering and Repeating Childhood Trauma. In A. Lieblich, D. P. McAdams \& R. Josselson (Eds.), The Narrative Basis of Psychotherapy (pp. 89-109). American Psychological Association.

Spector-Mersgel, G. (2011). Mechanisms of Selection in Claiming Narrative Identities: A Model for Interpreting Narratives'. Qualitative Inquiry, 17(2), 172-185. http://doi.org/10.1177/1077800410393885

Tammaru, T., Haukanomm, K., \& Anniste, K. (2010). The formation and development of the Estonian diaspora. Journal of Ethnic and Migration Studies, 36(7), 1157-1174.

http://doi.org/10.1080/1369183X.2010.481614

Teski, M. C., \& Climo, J. J. (1995). The labyrinth of memory: ethnographic journeys. Bergin \& Garvey.

Thompson, P., \& Bauer, E. (2005). Sources of Aid and Resilience and Points of Pain in Jamaican Migrant Families. Revue Europeenne Des Migrations Internationales, 21(3). http://doi.org/10.4000/remi.2502

Thornberg, R., \& Charmaz, K. (2014). Grounded Theory and Theoretical Coding. In U. Flick (Ed.), Sage Handbook of Qualitative Analysis. (pp. 153-169). Sage. http://doi.org/10.4135/9781446282243.n11

Tonkin, E. (1992). Narrating our pasts: the social construction of oral history. Cambridge University Press. 
UNHCR (2018). The Global Report on Refugees.

Ward, S. (2003). On Shifting Ground: Changing Formulations of Place in Anthropology. The Australian Journal of Anthropology, 14(1), 80-96. http://doi.org/10.1111/j.1835-9310.2003.tb00222.x

Weingarten, K. (2003). Common shock: Witnessing violence every day: How we are harmed, how we can heal. Dutton/Penguin Books.

Wilmsen, B. (2013). Family separation and the impacts on refugee settlement in Australia. Australian Journal of Social Issues, 48(2), 241262. http://doi.org/10.1002/j.1839-4655.2013.tb00280.x

William R. P. (2013). Understanding Syria: From Pre Civil was to Post Asad. The Atlantic, December, 10.

Aminul Islam is Head of The Curriculum for Creativity and Innovation Program at the Estonian Entrepreneurship University of Applied Sciences and PhD Student at the Institute of International and Social Studies at the Tallinn University.

Email: aminulislam80@yahoo.com, aminul@tlu.ee 


\section{Developmental Performance Ranking of SAARC Nations: An Aplication of TOPSIS Method of Multi-Criteria Decision Making}

Neeraj Narayan

Banaras Hindu University

Kaushalendra Kumar Singh

Banaras Hindu University

Ujjaval Srivastava

National Statistical System Training

Academy

Abstract

To be developed, nations are trying to cope up with the fast-changing economy and technology of the world. But the development of a nation does not depend only on these two factors rather several other indicators are essential to a country's development. The present study deals with the progress of the SAARC (South Asian Association for Regional Cooperation) countries towards development through social, economic and environmental stability. This study aims at analyzing the comparative developmental performance of the SAARC nations in accordance with the Millennium Development Goals (MDGs) and Sustainable Development Goals (SDGs). In this study, we have prioritized the 8 SAARC nations based on 4 indicators (economic, demographic, health and environment indicators) and 20 variables using the multi-criteria decision-making method (MCDM). The result showed that Sri Lanka has prioritized 1 st followed by Bhutan. India has been ranked 4th and Afghanistan was least prioritized.

Keywords: sustainable development, SAARC nations, multi-criteria decision making, TOPSIS, prioritization 


\section{Clasificación del Desempeño del Desarrollo de las Naciones de SAARC: Una Aplicación del Método TOPSIS de Toma de Decisiones de Criterios Múltiples}

Neeraj Narayan

Banaras Hindu University

Ujjaval Srivastava

National Statistical System Training

Academy
Kaushalendra Kumar Singh

Banaras Hindu University

\section{Resumen}

Para desarrollarse, las naciones están tratando de hacer frente la rapidez con la que cambian la economía y la tecnología en el mundo. Pero el desarrollo de una nación no depende solo de estos dos factores, sino de varios otros indicadores esenciales para el desarrollo de un país. El presente estudio aborda el progreso de los países de la SAARC (Asociación de Asia Meridional para la Cooperación Regional) hacia el desarrollo a través de la estabilidad social, económica y ambiental. El objetivo es analizar el desempeño comparativo del desarrollo de las naciones SAARC de acuerdo con los Objetivos de Desarrollo del Milenio (ODM) y los Objetivos de Desarrollo Sostenible (ODS). Hemos priorizado las 8 naciones de la SAARC en base a 4 indicadores (económicos, demográficos, de salud y ambientales) y 20 variables utilizando el método de toma de decisiones con criterios múltiples (MCDM). El resultado mostró que Sri Lanka ha priorizado primero seguido por Bután. India ocupó el cuarto lugar y Afganistán recibió menos prioridad.

Palabras clave: desarrollo sostenible, naciones SAARC, toma de decisiones multicriterio, TOPSIS, priorización 


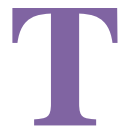

he present age is the age of globalization, co-operation and developing international relations. To withstand in this fastunderdeveloped countries want to attain the status of the developed nation. So, do the South Asian Association for Regional Cooperation (SAARC) nations comprising of eight nations i.e., Afghanistan, Bangladesh, Bhutan, India, Maldives, Nepal, Pakistan and Sri Lanka, desire the same. SAARC nations are concerned with economic and human capital i.e., an essential requirement by any nation to change its status from being developing to developed; these are used as a resource to support the economic and social development of nations. The focus of SAARC nations is not only on the development, but they are more focused on sustainable development; sustainable development is a development that meets the needs of the current generations without compromising the needs of future generations. Governments and societies of this organization (SAARC) seek economic and social growth but at the same time, it is also concerned about its impact on natural and social environments. These countries are concerned about developing their nation but also about the inequality, the possibilities of new forms of exclusions as the technology expands, the quality of life and health of children, the elderly and individuals and groups confronting social and economic disadvantages (Healy \& Côté, 2001). These nations are experiencing extensive development due to recent policies and trends in recent decades. To achieve social and economic sustainable development, we need to recognize the resources and opportunities for their exploitation (Andrade et al., 2015).

The strength and development of any nation today is not measured only in terms of military and defense capacity but also lies in terms of how a nation is able to promote trade relations, investments and economic integration within the region and globally as well (Tønnesson, 2005).From the very beginning of the formation of SAARC, there have been tremendous improvements in the member nations owing to the realization of regional cooperation and development and recognizing the sense of enhancing the regional economic, social and cultural development. At the same time advocating the revival of the SAARC organization by granting the practical implementation of plans and policies and turning this weak region into the 
potentially developed region (Shaheen, 2013). Government and policymakers often face difficulties in making complex decisions that will help in the growth of a nation. These difficulties arise mainly due to a lot of factors or indicators required in making decisions as well as their interdependencies with each other, creating trouble for decision-makers to understand the problem (Zavadskas et al., 2016). The extent of factors and their interactions causes complexity in making decisions for policy and planning makers (Witlox, 2005). The ranking of India is 131 among 188 nations according to the 2016 Human Development Report released by the United Nations Development Programme (UNDP) (3rd among SAARC nations). Sri Lanka (73) and Maldives (105) are ahead of India and Bhutan (132), Bangladesh (139), Nepal (144), Pakistan (147) and Afghanistan (169) got places after India (Jāhāna, 2016). HDI ranking is based on only 3 indicators: Health (life expectancy at birth), Education (mean years of schooling and expected years of schooling) and income (Gross National Income per capita in PPP\$). But there can be numerous other parameters (demographic, economic, health and social, etc.) on which we can rank these nations, but a country ranked first on one indicator may fall at last position at the other indicators. So, dealing with all parameters simultaneously is a difficult task. Surmounting this difficulty, the above problem can be considered a problem of multi-criteria decision making (MCDM).

MCDM refers to a set of methods which deal with searching for alternatives in the presence of multiple, usually conflicting, criteria (Jiang et al., 2017). For a given series of alternatives and decision criteria, MCDM aims to give ranking, preference, and sorting of alternatives from least preferred to most preferred. The technique for Order Performance by Similarity to Ideal Solution (TOPSIS) is one of the methods of MCDM to prioritize the alternatives. It was originally developed by Hwang and Yoon in 1981 (Hwang \& Yoon, 1981) and further developed by Yoon in 1987 (Yoon, 1987).

TOPSIS is a method that is based on the concept that the chosen alternative is the shortest distance from the positive ideal solution (PIS) and the longest distance from the negative ideal solution (NIS). The advantages of TOPSIS are that it is a simple, rationally, comprehensible concept, good computational efficiency and the ability to compute the relative importance 
of each alternative in the simple mathematical form (Yeh, 2002). The motivation behind working on SAARC nations is that SAARC countries are home to 23 percent of the world population which are very much dissimilar in terms of their demographic sizes and stages of socio-economic development. The SAARC region shares the second largest concentration of the poor population after Sub-Saharan Africa (Hanushek \& Wößmann, 2007).

In the present study, we have taken certain parameters that govern the sustainable development of the nation. The economic, demographic, health, employment, and environmental indicators vary from place to place. So, prioritizing the nations is based on these indicators using the technique of TOPSIS, multi-criteria decision making.

\section{Scientific Literature Review}

The three pillars of HDI calculations are life expectancy, education, and per capita income. Based on these averages, we measure a country's level of social welfare. But these averages provide us limited information about distribution within countries. Human development is not based on only these three factors rather it should be all-round development. Corresponding to the HDR, Human development is realized most essentially by having a long and healthy life, being educated, and having a decent standard of living and these can be achieved by political freedom and guaranteed human rights involving several factors which are considered in our parameters such as access to safe drinking water, electricity, improves sanitation facilities, etc. Here the question arises is that themeasure of human development is based on only the three factors considered in HDI.

The World Commission on Environment and in 1987 laid down the notion of sustainable development (inter- and intra-generational environmental and social justice) on the international agenda (Brundtland, 1987). Despite the works of different organizations in this field, international inter-governmental meetings and authoritative declarations, the global social, economic and environmental indicators are found to be stagnant in the role of human development. The sustainable development worldwide can be achieved if we focus on the health, self-realization, access to minimum 
necessary materials, clean and diverse environment, education, etc.Hence, a broad display of newfangled substitutes of HDI has unrolled embracing a wide range of indicators such as Michael Porter's Social Progress Index (Porter et al., 2014) towards further particular alternatives, for instance, Helliwell et al. (2016) Ranking of Happiness or the New Economics Foundation's Happy Planet Index (Comim, 2016). There was a time when Morris's (1978) Physical Quality of Life Index was considered as a stern alternative to the HDI.

The existing measure of economic and social welfare is GNI per capita in HDI which ignores the distribution of income among individuals (Marcuss \& Kane, 2007; McCulla \& Smith, 2007). Dissemination of income among individuals augments personal and social wellbeing which GNI per capita fails to assess (Kerry et al., 2012). Various goals of developments such as cultural differences are flouted by GNI per capita (Henderson, 1996), superintending the aftermaths of mounting social-economic-politicalecological disparities. HDI excludes the environment, overlooking the environmental costs, natural resources diminution rates, which is an essential factor in human as well as a nation's growth (Giannetti et al., 2015). HDI does not take into account the green GDP that targets to apprehend the real stance of the natural resources of the country. Most nations in the race of development have utterly snubbed the economic aspects of the misuse of the environment. Including the environmental factors will measure the country's preparation for sustainable development. Another important aspect lacked by HDI is unemployment. Creating and initiating strategies for expressive and dynamic work for young generations is one of the important targets of the Millennium Development Goals (Taner et al., 2011) and can be further considered as a fundamental human right. Employment institutes the indispensable tool for harmony, food security, and human development. Escalating employment levels nurtures economic growth and pave paths for accomplishing sustainable development. Therefore, in our study, we have tried to propose the key parameters for the new and natural vision of sustainable human development, which is going to be in accordance with the international strategies of sustainable development and millennium development goals. 


\section{Materials and Methods}

The present study is the Ranking of SAARC countries based on several indicators. The study area is for the countries Afghanistan, Bhutan, Bangladesh, India, Maldives, Nepal, Pakistan, and Sri Lanka. The data was taken from the World Bank database of the year 2016 for imports and exports of goods and services, GDP growth rate, unemployment $\%$ of labor force and age dependency ratio; 2015 for improving sanitation facilities, improved water sources, forest area, life expectancy at birth for both males and females, maternal mortality ratio, infant mortality rate, adult literacy rate, fertility rate, crude birth and death rates, and urban population; 2014 for health expenditure. Here, we have selected 20 parameters for ranking these countries which are responsible for the growth and development of a country. These parameters can be classified in Economic, demographic, health and environmental indicators.

The first indicator included in our study isan economic indicator that contains four variables, namely, imports and exports of goods and services (OECD, 2018a), GDP growth (OECD, 2018b) and total unemployment (OECD, 2018e). Importing and exporting assist in the growth of the national economies and magnify the global market. Expanding exports create employment opportunities and being a component of aggregate demand, it creates demand in the economy as well as plays a crucial role in deciding the current deficit. GDP growthis the total of gross value added by all the producers residing in an economy in addition to any product taxes and exclusion of any subsidies not included in the value of the products. The growth of an economy is measured by the change of its output and the real income of its residents (OECD, 2018b). The countries having low rates of unemployment can have disguised of substantial poverty whereas the countries having a high level of economic development but low rates of poverty can have high rates of unemployment. There will be a less or ineffective contribution to the growth and development of a nation if there is a presence of unemployed or underemployed youths. [SDG Indicator 8.5.2]

The second indicator is the demographic indicator which has six variables viz. Adult literacy rate (World Bank, 2015), total fertility rate, crude birth (OECD, 2018a) and death (Guest, 1974) rates, urban population 
and age dependency ratio (Bongaarts, 2001). A high literacy rate indicates the ability of an education system to provide a large population with opportunities to acquire literacy skills and can also be used as a proxy indicator to measure the effectiveness of an education system (World Bank, 2015). Developing nations have high fertility rate as it adheres to traditional religious beliefs, lack of knowledge of contraceptives and access to it, owing to lower level of female education, desire of children for their labors and as a support in old age whereas in developed nations having lower fertility rates often correlated with prosperous wealth, quality education, high degree of urbanization and other factors. To being developed, every developing nation tries to reduce its fertility rate. The birth rate is an important issue of concern for policymakers and the government of a country. It varies with nations to increase or decrease the birth rate e.g. countries like Italy and Malaysia seek to increase their birth rates while China seeks to decrease their birth rate (One-Child policy). Policies to increase the crude birth rate are called pronatalist policies and policies to reduce the crude birth rate are called antinatalist policies. So, for any nation, the crude birth rate is an important character in the development of the nation. The crude death rate can be considered as a good indicator of the general health status of a country. Crude Death Rate helps in deciding the health policies of a nation. So, statistics on death are crucial for the growth of any developing nation (Statistical Office United Nations, 1991). The global significance of urbanization can be seen through the demographic transition from rural to urban, and movement from an agriculture-based economy to mass industry, technology, and service in search of more favorable resolutions of social and environmental problems. There are more job opportunities, health care facilities, and other modern services at urbanized centers. Urbanization also provides opportunities for social mobilization and women's empowerment (UNPD, 2014). The age composition of a country's population partly indicates the development pattern of the country and has different impacts on the environment and resources owing to the different age structures. Therefore, to analyze the resource use and formulate future policy and planning goals, the age structure of a population is of great use (World Bank, 2017). 
The third indicator is health indicator which has five variables that are the infant mortality rate (Reidpath \& Allotey, 2003), the under-five mortality rate (UN IGME, 2017), life expectancy at birth (OECD, 2018c), total health expenditure (WHO, n.d.) and Maternal Mortality Ratio. IMR is an important indicator to know the health status of a country. Since there are less data on incidence and prevalence of diseases, the mortality rates for different age groups (infants, under five, etc.) are of great importance in identifying the vulnerable populations and can also be used to compare socioeconomic developments across the countries (UNICEF, 2017). Under-five mortality rates are a leading indicator that shows child health as well as the overall development of a nation. This indicator can be used to identify the susceptible population as the data on the incidence and prevalence of diseases can be unavailable and it can also be used to compare the socioeconomic development of the countries (UNICEF, 2017). An increase in life expectancy at birth can be credited to the increase in the standard of living, improved education facilities, improved health facilities and gain in other socio-economic factors. The creation of institutions and defining the action plan to promote, restore and maintain the health status of the population is of key importance (Shreshta, 2000). To reduce the incidence and prevalence of diseases and to further reduce the mortality and morbidity, there is a need for strengthening health system through financing, service delivery, workforce, governance and information which in turn will lead to a better development of nation (WHO et al., 2015). The effective capacity of the health system of a nation can be identified by this indicator as it signifies the inadequate nutrition and general health of women as well as the lack of fulfillment of their reproductive rights.

The fourth indicator is an environment that includes four variables given as Forest area, Improved sanitation facilities (WHO \& UNICEF, 2017), Improved water source (WHO \& UNICEF, 2017) and Access to electricity. There has been a tremendous increase regarding the focus on the conservation of biodiversity owing to the increasing threats to biodiversity in the name of development. Destruction of forests and exploitation of its resources to meet the need of the population has become a vital concern for conserving the flora and fauna. Information on forest areas helps many international as well as government agencies in formulating plans and 
policies concerning the development of the nation. Sanitation is fundamental to human development. Several international organizations use hygienic sanitation facilities as a measure of progress to fight against poverty, disease, and death. Proper sanitation access is considered as the right of humans. Inadequacies in sanitation facilities cause major diseases and have a significant adverse effect on human health. Water is a life-supporting element for humans, animals, and plants. Meagerness in water sources causes major diseases (diarrhea, cholera, etc.) world-wide. Global access to a safe water source can help in reducing the waterborne disease and illnesses and lead to improved health, poverty reduction and socio-economic development. Economic growth cannot be achieved without electricity. It is impossible for the functioning of the factories, shops, growing crops, etc. without access to any form of energy. Electricity is an indispensable form of energy for human development.

\section{TOPSIS Model}

This is a widely used method in solving real-life problems (Yang \& Hung, 2007) allowing the decision-makers to incorporate complete information on given criteria and provide us optimal solutions or alternative ranking. This method consists of searching among the given alternatives that are closest to the ideal solution and farthest from the non-ideal solution at the same time (Marković, 2016). TOPSIS results depend on the assignment of the weights to the variables by the decision-makers. A set of weights $W=\left\{W_{1}, W_{2}, \ldots\right.$, $\left.\mathrm{Wn}_{\mathrm{n}}\right\}$ is assigned to the parameters such that $\sum_{j=1}^{n} w_{j}=1$.

\section{TOPSIS algorithm}

Step 1: The first step in processing the TOPSIS method is the construction of the decision matrix (DM) consisting of $m$ alternatives and $n$ criteria.

Where Ai's are the alternatives and $\mathrm{C}_{\mathrm{j}}$ 's are the criteria or variables based on which we will be finding our ideal solutions and $\mathrm{X}_{\mathrm{ij}}$ 's are the interactions of the alternatives and the criteria. 


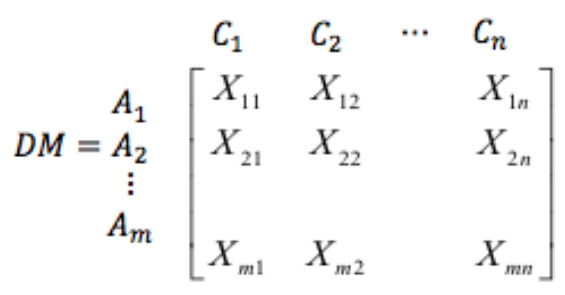

Step 2: Now, we will normalize the decision matrix to make the dimension of the variable free allowing comparisons across the criteria. Since the various criteria in the decision matrix are measured in the different units, the scores in the decision matrix need to be normalized. Each entry in the normalized matrix $\mathrm{R}$ is obtained by the formula given below:

For maximum type criteria,

$$
\boldsymbol{R}=\frac{\boldsymbol{x}_{i j}}{\sqrt{\sum_{i=1}^{m} X_{i j}^{2}}}
$$

For minimum type criteria,

$$
\boldsymbol{R}=\mathbf{1}-\frac{\boldsymbol{X}_{\tilde{i} \boldsymbol{j}}}{\sqrt{\sum_{i=1}^{m} \boldsymbol{X}_{i \mathfrak{i}}^{2}}}
$$

Here, equation (2) is for the parameters which have a positive impact on the development of a nation owing to their higher values and equation (3) is for those parameters which have a negative impact on the development of a nation owing to their higher values. So that assigning the proper weights to the parameters according to their importance is feasible in calculating their prioritization (Marković, 2016).

$\mathrm{R}$ matrix is given as:

$$
R=\left[\begin{array}{ccc}
r_{11} & \cdots & r_{1 n} \\
\vdots & \vdots & \vdots \\
r_{m 1} & \cdots & r_{m n}
\end{array}\right]
$$


Step 3: To obtain the weighted normalized matrix, we multiply the $j_{\text {th }}$ column of $\mathrm{R}$ by $\mathrm{w}_{\mathrm{j}}$, normalized decision matrix $\mathrm{V}$ is given as follows:

$$
\boldsymbol{V}=\left[\begin{array}{ccc}
v_{11} & \cdots & v_{1 n} \\
\vdots & \ddots & \vdots \\
v_{m 1} & \cdots & v_{m n}
\end{array}\right]=\left[\begin{array}{ccc}
r_{11} w_{1} & \cdots & r_{1 n} w_{n} \\
\vdots & \ddots & \vdots \\
r_{m 1} w_{1} & \cdots & r_{m n} w_{n}
\end{array}\right]
$$

Step 4: Now, we will obtain the positive ideal solution and negative ideal solution denoted by $S_{+}$and $S$ - respectively.

$$
\begin{aligned}
S .=\left[\left\{\max \left(v_{i j} \mid \mathbf{i}=1,2, \ldots, m\right) \mid j \in J-\right\},\left\{\min \left(v_{i j} \mid \mathbf{i}=1,2, . ., m\right) \mid j \in J+\right\}\right] \\
=\left\{S_{-j}, j=1,2, \ldots, n\right\}[\text { ideal alternative coordinates] }
\end{aligned}
$$

$S_{+}=\left[\left\{\min \left(v_{i j} \mid i=1,2, \ldots, m\right) \mid j \in J.\right\},\left\{\max \left(v_{i j} \mid \mathbf{i}=1,2, \ldots, m\right) \mid j \in J_{+}\right\}\right]$

$=\left\{S_{+j}, j=1,2, \ldots, n\right\}$ [non-ideal alternative coordinates]

Where,

$\mathrm{J}_{+}=\{\mathrm{j}=1,2, \ldots, \mathrm{n} \mid \mathrm{j}$ associated with the criteria having a positive impact $\}$

$J_{-}=\{j=1,2, \ldots, n \mid j$ associated with the criteria having a negative impact $\}$

Step 5: Now, we will calculate the distance $D_{i+}$ of each alternative $A_{i}$ from the ideal solution by the given formula:

$$
D_{i}^{+}=\sqrt{\sum_{j=1}^{n}\left(v_{i j}-S_{j}^{+}\right)^{2}}
$$

$\mathrm{i}=1,2, \ldots, \mathrm{m}$, the distance of the $\mathrm{i}_{\text {th }}$ alternative form the ideal point. We will calculate the distance $\mathrm{D}_{\mathrm{i}-}$ of each alternative $\mathrm{A}_{\mathrm{i}}$ from the non-ideal solution by the given formula:

$$
D_{i}^{-}=\sqrt{\sum_{j=1}^{n}\left(v_{i j}-S_{j}^{-}\right)^{2}}
$$

$\mathrm{i}=1,2, \ldots, \mathrm{m}$, the distance of the $\mathrm{i}_{\text {th }}$ alternative form the non-ideal point. 
Step 6: Now, we will calculate the relative similarity of the alternatives from the ideal and non-ideal point using the given formula:

$\boldsymbol{C}_{i}=\frac{\boldsymbol{D}_{\bar{i}}^{\bar{i}}}{\boldsymbol{D}_{\overline{\mathrm{i}}}^{-}+D_{\bar{i}}^{+}}, 0 \leq C_{i} \leq 1, \mathrm{i}=1,2, \ldots, \mathrm{m}$

If $C_{i}=1$, then $A_{i}=S_{+}$and if $C_{i}=0$, then $A_{i}=S_{-}$, therefore $A_{i}$ is closer to $S_{+}$if $C_{i}$ is closer to 1 .

Step 7: Now, we will be setting up the rank according to the bigger $C_{i}$, this means that the bigger $C_{i}$ would be the better alternative.

\section{Results and Discussions}

In our study, we have considered several factors that are broadly classified into four major indicators (economic, demographic, health and environment indicators) which are further classified into several important indicators that play an important role in human development. Here, we have a total of 20 variables to measure the growth of a human. Hence, we used the TOPSIS method mentioned in the materials and methods to deal with these 20 variables simultaneously and our decision matrix for the variables is given in Table 1. After making the decision matrix, we will now have normalized the decision matrix using the equation (2) for the maximum type criteria which have a positive impact on the development of a nation owing to the higher values (e.g. Exports of Goods and Services, GDP Growth Rate, Access to Electricity, Improved Sanitation, Water Facilities, Forest Area, Life Expectancy at Birth Males and Females and Urban Population percentage) and equation (3) for the minimum type criteria which have negative impact on the development of nation owing to the higher values (e.g. MMR, IMR, Under Five Mortality Ratio, TFR, Health Expenditure, CBR, CDR and Imports of Goods and Services) given in the materials and methods. A normalized matrix is given in Table 2. After considering the relative importance of each variable, the weights to these variables were allotted such that the variables which are crucial in the growth and development of a nation were allotted higher weights and rest were allotted relatively low weights. The weights assigned to these variables are given in Table 3 . Using 
equation (5) in the materials and methods section, we constructed the weighted normalized decision matrix is given in Table 4.

Using the equation (6) and (7) from the material and methods section, we obtained the positive and negative ideal solution, given in Table 5. Using equation (8) and (9) in the materials and method section, we obtained the distance of each alternative from the positive and negative ideal solution is given in Table 6 . Now, we obtained the relative similarity of the alternatives from the ideal and non-ideal point using the equation (10) given in the materials and method section based on which we ranked the countries is given in Table 7.

The result was found to be efficient using this technique. Ranking of the countries has been found in the following manner: Sri Lanka $\left(1_{\mathrm{st}}\right)$, Bhutan (2nd), Maldives (3rd), India (4th), Bangladesh (5th), Nepal (6th), Pakistan (7th) and Afghanistan (8th). From the decision matrix, we can observe the evidence in support of the result obtained. Since TOPSIS is an MCDM technique which considers several factors simultaneously for prioritization of alternatives, so here we can observe that Sri Lanka is performing better than other SAARC nations in several parameters such as Unemployment \% of total labor force, Improved sanitation facilities (\% of population with access), Maternal mortality ratio, Infant mortality rate, Life expectancy at birth (both males and females), Age dependency ratio (\% of working-age population), Crude birth and death rates. Sri Lanka has also been found performing above average in other parameters among the SAARC nations.

India has been ranked (4th) and it can be justified by comparing the variables with the top prioritized countries. The empirical evidence in support of the result is as follows: India's Exports of goods and services are $19.9 \%$ of GDP which is lower than all the three top prioritized countries Bhutan (32.9), Maldives (91.4) and Sri Lanka (21). India has higher Unemployment $\%$ of the total labor force of 3.5 which is greater than Bhutan (2.5). India has lower (a) access to electricity (\% of Population) of 79.2 than Bhutan (100), Maldives (100) and Sri Lanka (92.2); (b) improved sanitation facilities (\% of population) of 40 than Bhutan (50), Maldives (98) and Sri Lanka (95); (c) life expectancy at birth both females and males of 70 and 67 respectively than Maldives $(78,76)$, Sri Lanka $(78,72)$ and Sri Lanka $(70,70)$; (d) adult literacy rate (population 15+ years both sexes\%) of 72 than 
Maldives (99) and Sri Lanka (93); (e) urban population \% of 33 than Bhutan (39) and Maldives (46); these factors have a positive impact on the development of a nation and owing to higher values show higher growth of a nation. India has higher (a) MMR of 174 than Bhutan (148), Maldives (68) and Sri Lanka (30); (b) IMR of 38 than Bhutan (27), Maldives (7) and Sri Lanka (8); (c) under-five mortality ratio of (48) than Bhutan (33), Maldives (9) and Sri Lanka (10); (d) total fertility rate of (2.4) than Bhutan (2), Maldives (2.1) and Sri Lanka (2.1); (e) age dependency ratio (\% of workingage population) of 52 than Bhutan (47), Maldives (47) and Sri Lanka (51); (f) CBR of 20 than Bhutan (17) and Sri Lanka (16); (g) CDR of 7 than Bhutan (6) and Maldives (4); these are the factors which imparts negative impact on the growth of the nation's owing to their higher values. The result also shows that Sri Lanka is moving in the right direction towards attaining the Sustainable Development Goals.

\section{Conclusions}

This study measured the knowledge level of awareness regarding the development of nations concerning the factors associated with the economic development, accessibility to the health services, and demographic approach of the countries, employment enrollment factor, and proportion of forest land. Thus, the development of nations with the factors thereof means keeping with the pace of the fast-changing world and maintaining the social stability of nations and considering the factors associated with the environment.

In recent times multi-criteria decision-making problem (MCDM) has found the TOPSIS algorithm which is widely used to prioritize the multi attributes in making decisions and help us in making an optimum decision based on several factors or variables.

Here, the TOPSIS algorithm helped us in prioritizing the SAARC nations based on the five indicators and twenty-two variables. This study showed us that Sri Lanka is performing well towards its development followed by Bhutan. India has been found in 4th position followed by Bangladesh and posts to the Maldives. In our study, we observed that Bhutan is two places above India in contrary to the HDI ranking where Bhutan's ranking is below 
India. This result is attributed to the large forest cover in Bhutan and lower IMR, TFR, MMR than India and a greater ratio of access to electricity, improved sanitation facilities and improved drinking water as compared to India. Therefore, we can say that Bhutan is better in proratingtheir resources following the sustainable development and millennium development goals than India. The result is more analogous to the Human Development Ranking (HDI) published on 21st March 2017 with the following rankings of the considered countries in the study: Sri Lanka (73), Maldives (105), India (131), Bhutan (132), Bangladesh (139), Nepal (144), Pakistan (147) and Afghanistan (169). The ranking of the SAARC countries is shown in table 8.

\section{References}

Bongaarts, J. (2001). Dependency burdens in the developing world. In N. Birdsall, A. C. Kelley \& S. Sinding (Eds.), Population matters. Demographic change, economic growth, and poverty in the developing world (pp. 55-64). Oxford University Press.

Brundtland, G. H. (1987). Our common future-Call for action. Environmental Conservation, 14(4), 291-294. http://doi.org/10.1017/S0376892900016805

Comim, F. (2016). Beyond the HDI? Assessing alternative measures of human development from a capability perspective. Background paper of the Human Development Report 2016.

de Andrade, L. O., Pellegrini Filho, A., Solar, O., Rígoli, F., de Salazar, L. M., Serrate, P. C., Ribeiro, K. G., Koller, T.S., Cruz, F. N., \& Atun, R. (2015). Social determinants of health, universal health coverage, and sustainable development: case studies from Latin American countries. The Lancet, 385(9975), 1343-1351. http://doi.org/10.1016/S0140-6736(14)61494-X

Giannetti, B. F., Agostinho, F., Almeida, C. M. V. B., \& Huisingh, D. (2015). A review of limitations of GDP and alternative indices to monitor human wellbeing and to manage eco-system functionality. Journal of Cleaner Production, 87, 11-25. http://doi.org/10.1016/j.jclepro.2014.10.051 
Guest, A.M. (1974). The relationship of the crude birth rate and its components to social and economic development. Demography, 11(3), 457-472. https://doi.org/10.2307/2060438

Hanushek, E.A., \& Wößmann, L. (2007). The role of education quality for economic growth. The World Bank.

Healy, T., \& Côté, S. (2001). The Well-Being of Nations: The Role of Human and Social Capital. Education and Skills. Organisation for Economic Cooperation and Development.

Helliwell, J. F., Layard, P. R., \& Sachs, J. (Eds.). (2016). World happiness report 2016 update: volume I. Sustainable Development Solutions Network.

Henderson, H. (1996). Measuring Progress: Not by GNP Alone. The Light Party https://lightparty.com/Visionary/MeasuringProgress.html

Hwang, C. L., \& Yoon, K. (1981). Methods for multiple attribute decision making. In Multiple attribute decision making. Methods and Applications A State-of-the-Art Survey (pp. 58-191). Springer.

Jāhāna, S. (2016). Human development report 2016: human development for everyone. United Nations Publications.

Jiang, S., Li, Y., Jiang, P., \& Gan, L. (2017). Evaluating the Quality Performance of Reconstructive Community Public Health Service Based on Weighted TOPSIS Method. In Proceedings of the Tenth International Conference on Management Science and Engineering Management (pp. 113-123). Springer.

Marcuss, R. D., \& Kane, R. E. (2007). Us national income and product statistics. Survey of Current Business, 87, 32-46.

Marković, Z. (2016). Modification of TOPSIS method for solving of multicriteria tasks. Yugoslav Journal of Operations Research, 20(1). http://doi.org/10.2298/YJOR1001117M

McCulla, S. H., \& Smith, S. (2007). Measuring the Economy: A primer on GDP and the National Income and Product Accounts. Bureau of Economic Analysis, US Departament of Commerce.

Morris, M. D. (1978). A physical quality of life index. Urban Ecology, 3(3), 225-240. http://doi.org/10.1016/0304-4009(78)90015-3 
OECD (2018a). Fertility rates (indicator). OECD iLibrary. http://doi.org/10.1787/8272fb01-en

OECD (2018b). Gross domestic product (GDP) (indicator). OECD iLibrary. http://doi.org/10.1787/dc2f7aec-en

OECD (2018c). Life expectancy at birth (indicator). OECD iLibrary. http://doi.org/10.1787/27e0fc9d-en

OECD (2018d). Trade in goods and services (indicator). OECD iLibrary. http://doi.org/10.1787/0fe445d9-en

OECD (2018e). Unemployment rate (indicator). OECD iLibrary. http://doi.org/10.1787/997c8750-en

Pickett, K. E., \& Wilkinson, R. (2012). The Spirit Level: Why Greater Equality Makes Societies Stronger. Bloomsbury Press.

Porter, M. E., Stern, S., \& Green, M. (2014). Social progress index 2014. Social Progress Imperative.

Reidpath, D. D., \& Allotey, P. (2003). Infant mortality rate as an indicator of population health. Journal of Epidemiology \& Community Health, 57(5), 344-346. http://doi.org/10.1136/jech.57.5.344

Shaheen, I. (2013). South Asian Association for Regional Cooperation (SAARC): Its Role, Hurdles and Prospects. IOSR Journal of Humanities and Social Science, 15(6), 01-09. http://doi.org/10.9790/0837-1560109

Shrestha, L. B. (2000). Population Aging In Developing Countries: The elderly populations of developing countries are now growing more rapidly than those in industrialized nations, thanks to health advances and declining fertility rates. Health affairs, 19(3), 204212. https://doi.org/10.1377/hlthaff.19.3.204

Satistical Office United Nations (1991). Handbook of Vital Statistics Systems and Methods, Volume 1: Legal, Organisational and Technical Aspects, United Nations Studies in Methods, Glossary, Series F, No. 35. United Nations.

Taner, M., Sezen, B., \& Mihc1, H. (2011). An alternative human development index considering unemployment. South East European Journal of Economics and Business, 6(1), 45-60. http://doi.org/10.2478/v10033-011-0005-z 
44 Narayan, Singh \& Srivastava-Performance Ranking SAARC Nations

Tønnesson, S. (2004). Globalising national states. Nations and Nationalism, 10(1-2), 179-194. http://doi.org/10.1111/j.13545078.2004.00162.x

UNICEF. WHO (2017). Progress on Drinking Water, Sanitation and Hygiene: 2017 Update and SDG Baselines. World Health Organization (WHO) and the United Nations Children's Fund (UNICEF).

UNICEF. WHO (2017). Progress on Drinking Water, Sanitation and Hygiene: 2017 Update and SDG Baselines. World Health Organization (WHO) and the United Nations Children's Fund (UNICEF).

United Nations Inter-agency Group for Child Mortality Estimation (UN IGME) (2017). Levels \& Trends in Child Mortality: Report 2017, Estimates Developed by the UN Inter-agency Group for Child Mortality Estimation. United Nations Children's Fund.

United Nations Population Division (2014). World Urbanization Prospects: 2014 Revision. United Nations.

WHO, UNICEF, UNFPA, World Bank Group, \& the United Nations Population Division. (2015). Trends in Maternal Mortality: 1990 to 2015. World Health Organization.

Witlox, F. (2005). Expert systems in land-use planning: An overview. Expert Systems with applications, 29(2), 437-445. http://doi.org/10.1016/j.eswa.2005.04.041

World Health Organization (n.d.). World Health Organization Global Health Expenditure database. World Health Organization. http://apps. who.int/nha/database

Yang, T., \& Hung, C. C. (2007). Multiple-attribute decision making methods for plant layout design problem. Robotics and Computerintegrated Manufacturing, 23(1), 126-137. http://doi.org/10.1016/j.rcim.2005.12.002

Yeh, C. H. (2002). A problem-based selection of multi-attribute decision-making methods. International Transactions in Operational Research, 9(2), 169-181. http://doi.org/10.1111/1475-3995.00348

Yoon, K. (1987). A reconciliation among discrete compromise solutions. Journal of the Operational Research Society, 38(3), 277-286. http://doi.org/10.1057/jors.1987.44 
Zavadskas, E. K., Mardani, A., Turskis, Z., Jusoh, A., \& Nor, K. M. (2016). Development of TOPSIS method to solve complicated decision-making problems-An overview on developments from 2000 to 2015. International Journal of Information Technology \& Decision Making, 15(03), 645-682. http://doi.org/10.1142/S0219622016300019 
46 Narayan, Singh \& Srivastava-Performance Ranking SAARC Nations

\section{Annexes}

Table 1.

Decision Matrix

\begin{tabular}{|c|c|c|c|c|c|c|c|c|c|c|c|c|c|c|c|c|c|c|c|c|}
\hline$\frac{\frac{5}{8}}{\frac{8}{8}}$ & 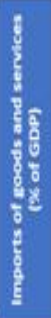 & 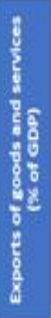 & 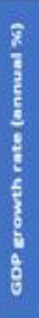 & 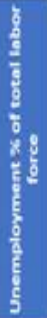 & 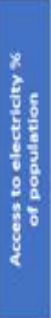 & 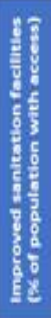 & 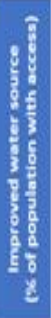 & 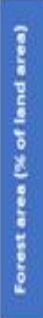 & 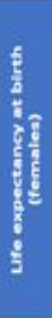 & 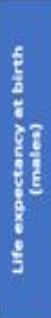 & 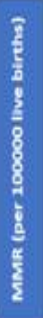 & 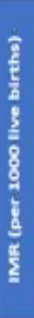 & 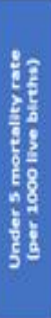 & 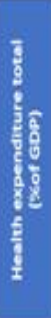 & 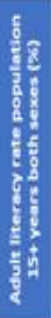 & 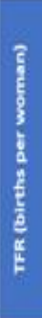 & 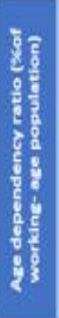 & $\frac{8}{8}$ & $\frac{8}{6}$ & $\begin{array}{l}\frac{8}{5} \\
\frac{5}{8} \\
\frac{8}{3} \\
\frac{8}{6} \\
\frac{5}{5} \\
\frac{5}{5}\end{array}$ \\
\hline Afghanistan & 49 & 69 & 22 & 8.5 & 89.5 & 32 & 55 & 21 & 62 & 60 & 396 & 66 & 91 & 8.2 & 38 & 4.7 & 85 & 33 & 8 & 27 \\
\hline Bangladesh & 21.3 & 16.6 & 7.1 & 4.1 & 624 & 61 & 87 & 11 & 73 & 71 & 176 & 31 & 38 & 2.8 & 61 & 2.1 & 51 & 19 & 5 & 35 \\
\hline Bhutan & 52.1 & 29.4 & 62 & 24 & 100 & 50 & 100 & 723 & 70 & 70 & 148 & 27 & 33 & 3.6 & 64 & 2 & 46 & 17 & 6 & 39 \\
\hline Indla & 20.6 & 192 & 7.1 & 35 & 79.2 & 40 & 94 & 238 & 70 & 67 & 174 & 38 & 48 & 4.7 & 72 & 2.4 & 52 & 20 & 7 & 33 \\
\hline Maldives & 89 & 93.8 & 4.1 & 32 & 100 & 98 & 99 & 33 & 78 & 76 & 68 & 7 & 9 & 13.7 & 99 & 2.1 & 47 & 21 & 4 & 4 \\
\hline Nepal & 39.4 & 10.7 & 0.6 & 3.2 & 84.9 & 45 & 92 & 25.4 & 71 & 69 & 258 & 29 & 3 & 5.8 & 65 & 2.2 & $\omega$ & 20 & 6 & 19 \\
\hline Pakistan & 15.8 & 8.7 & 5.7 & 5.9 & 97.5 & 64 & 91 & 19 & 67 & 65 & 178 & 66 & 81 & 26 & 56 & 3.5 & 65 & 29 & 7 & 39 \\
\hline Sritanka & 29.1 & 21.4 & 4.4 & 5 & 92.2 & 95 & 96 & 33 & 78 & 72 & 30 & 8 & 10 & 35 & 93 & 2.1 & 51 & 16 & 7 & 18 \\
\hline
\end{tabular}


Table 2.

Normalized Matrix

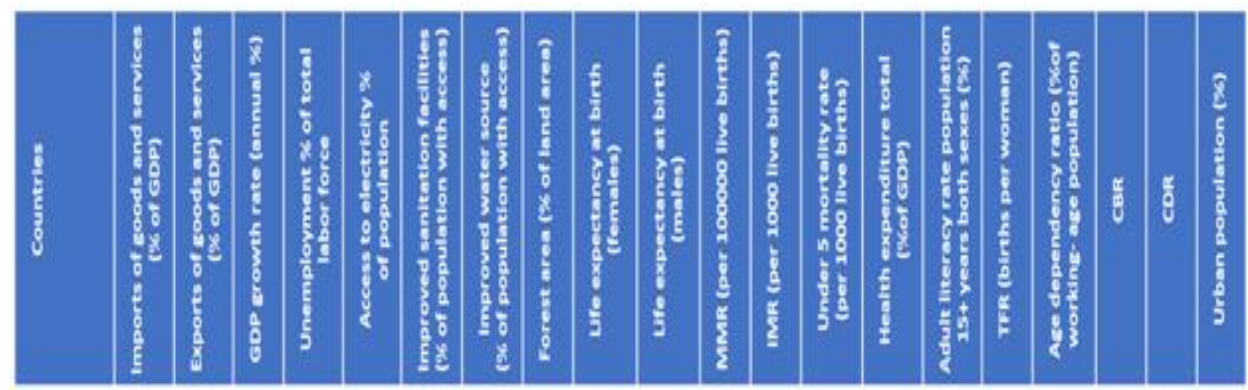

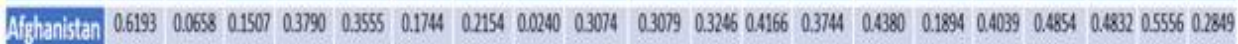

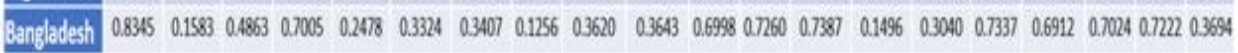

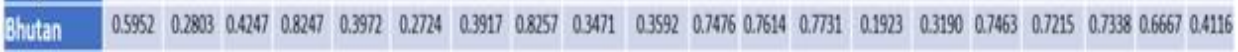
\begin{tabular}{lllllllllllllllllllllllllll}
\hline Indla & 0.8399 & 0.1830 & 0.4863 & 0.7443 & 0.3146 & 0.2179 & 0.3682 & 0.2718 & 0.3471 & 0.3438 & 0.7032 & 0.6641 & 0.5700 & 0.2511 & 0.3589 & 0.6956 & 0.68552 & 0.6058 & 0.6111 & 0.3483
\end{tabular}

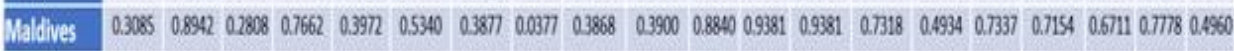

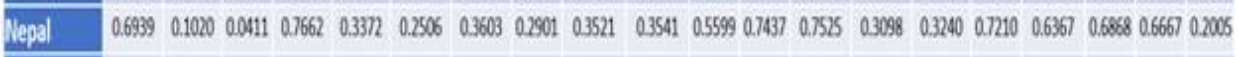

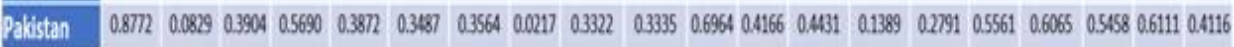
\begin{tabular}{llllllllllllllllllllll}
\hline Sillanka & 0.7739 & 0.2040 & 0.3014 & 0.6347 & 0.3662 & 0.5176 & 0.3760 & 0.3769 & 0.3868 & 0.3695 & 0.9488 & 0.9293 & 0.9312 & 0.1870 & 0.4635 & 0.7337 & 0.6912 & 0.7494 & 0.6111 & 0.1900
\end{tabular}

Table 3.

Weight assigned to the parameters

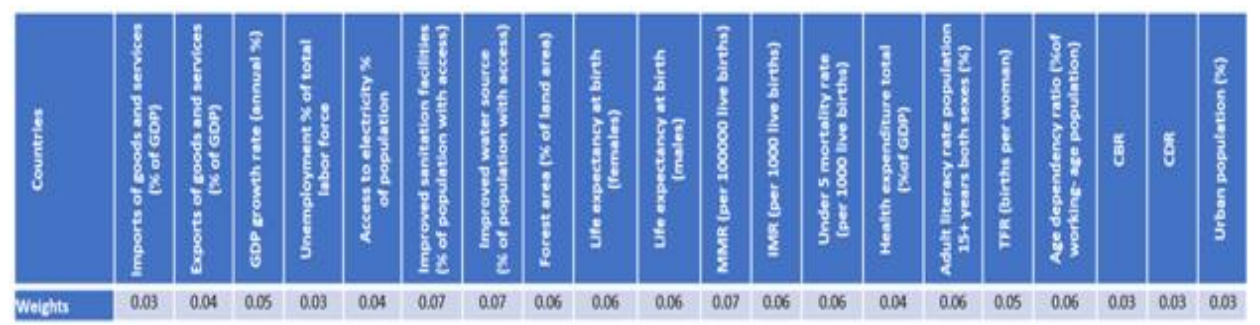




\section{Narayan, Singh \& Srivastava-Performance Ranking SAARC Nations}

Table 4.

Weighted Normalized Decision Matrix

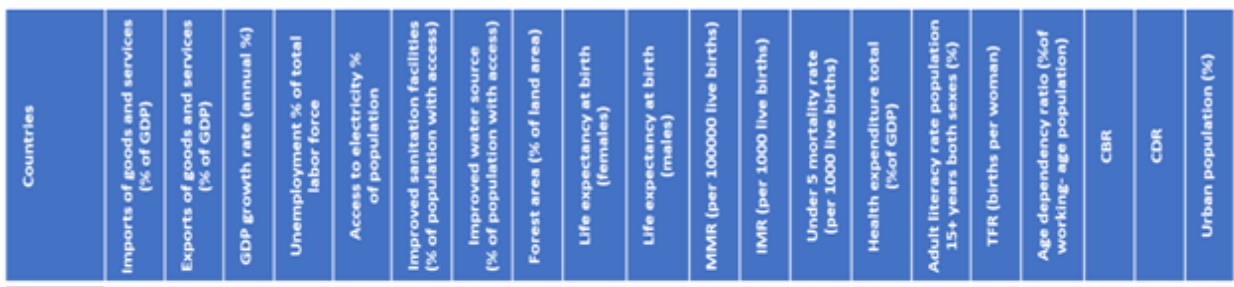

\begin{tabular}{|c|c|c|c|c|c|c|c|c|c|c|c|c|c|c|c|c|c|}
\hline ohat & 186 & 026 & 0.0075 & 0.0114 & 2142 & 0122 & 0151 & 0.0014 & 0.0184 & 0185 & 22270.0250 & 0.0225 & 0.0175 & 0114 & 0.0202 & 0291 & 0.014 \\
\hline inglades: & 250 & 3 & 243 & 0 & 099 & 2033 & 0239 & 0.0075 & 1217 & 00219 & 0.04900 .0436 & 0,0443 & 0.0060 & 0.0182 & 0.0367 & 0.0415 & 0211 \\
\hline , & 17 & 112 & c & 47 & 159 & 71 & 4 & 195 & ( & 6 & 7 & 0 & 7 & 91 & 73 & 133 & 0.02200 .0 \\
\hline India & 252 & 073 & 0.0243 & 0.0223 & 0126 & 0153 & 0.0258 & 0.0163 & 0,0208 & 0,0206 & 0.04920 .0398 & 0.0402 & 0.0100 & 0.0215 & 0.0348 & 0.0411 & 0.02060 \\
\hline ald & 0093 & 0.0358 & c & 0 & 59 & 0.0374 & 0.0271 & c & c & 4 & 0. & or & 33 & 6 & 367 & 0.0429 & 0.02010 .02 \\
\hline Ilonal & 208 & 041 & 0.0021 & 0.0230 & 0135 & 0175 & 0.0252 & 0.0174 & 0.0211 & 0,0212 & 0.03920 .0446 & 0.0451 & 0.0124 & 0.0194 & 0.0360 & 0.0382 & 0.0200 \\
\hline 100 & 0.0263 & 0.0033 & & 1 & 0155 & 0.0244 & 9 & ( & & ) & 0 & 0.0266 & 6 & 67 & 78 & 4 & $0.0107,00$ \\
\hline lanka & & & 15 . & & & & & & & & & & & & & c & wous \\
\hline
\end{tabular}

Table 5.

Positive and Negative Ideal Solution

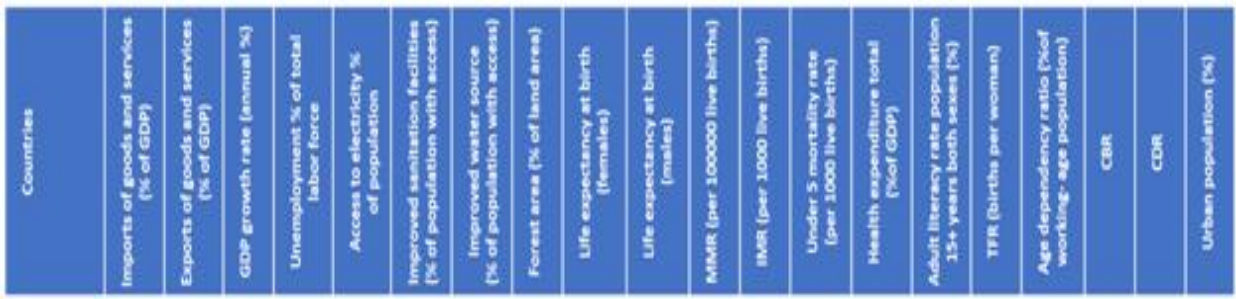

Sf $\quad 0.02630 .03580 .02430 .02470 .01590 .03740 .02740 .04950 .0232 \quad 0.02340 .06540 .05630 .05630 .02930002960 .03730 .04330 .02250 .02330 .0149$

Sf 0.00930 .00260 .00210 .01140 .00990 .01220 .01510 .00130 .01840 .01850 .02270 .02500002250 .00580 .01140 .02020 .02910 .0145001670 .0057 
Table 6.

Distance from Positive and Negative Ideal Solution

\begin{tabular}{|c|c|c|}
\hline Countries & $\boldsymbol{D}_{\boldsymbol{i}}^{+}$ & $\boldsymbol{D}_{\mathbf{j}}^{-}$ \\
\hline Afghanistan & 0.0996 & 0.0169 \\
\hline Bangladesh & 0.0648 & 0.0565 \\
\hline Bhutan & 0.0451 & 0.0763 \\
\hline India & 0.0613 & 0.0551 \\
\hline Maldives & 0.0516 & 0.0861 \\
\hline Nepal & 0.0670 & 0.0485 \\
\hline Pakistan & 0.0823 & 0.0424 \\
\hline Sri Lanka & 0.0470 & 0.0800 \\
\hline
\end{tabular}

Table 7.

Prioritization of Countries

\begin{tabular}{l|l|c|}
\hline Countries & $C_{i}$ & Ranking \\
\hline Afghanistan & 0.1454 & $\mathbf{8}$ \\
\hline Bangladesh & 0.4657 & $\mathbf{5}$ \\
\hline Bhutan & 0.6287 & $\mathbf{2}$ \\
\hline India & 0.4735 & $\mathbf{4}$ \\
\hline Maldives & 0.6253 & $\mathbf{3}$ \\
\hline Nepal & 0.4200 & $\mathbf{6}$ \\
\hline Pakistan & 0.3400 & $\mathbf{7}$ \\
\hline Sri Lanka & 0.6299 & $\mathbf{1}$ \\
\hline
\end{tabular}


50 Narayan, Singh \& Srivastava-Performance Ranking SAARC Nations

Table 8 .

Ranking of SAARC Nations

\begin{tabular}{|c|c|c|}
\hline Countries & $\boldsymbol{C}_{\boldsymbol{i}}$ & Ranking \\
\hline Sri Lanka & 0.6299 & $\mathbf{1}$ \\
\hline Bhutan & 0.6287 & $\mathbf{2}$ \\
\hline Maldives & 0.6253 & $\mathbf{3}$ \\
\hline India & 0.4735 & $\mathbf{4}$ \\
\hline Bangladesh & 0.4657 & $\mathbf{5}$ \\
\hline Nepal & 0.4200 & $\mathbf{6}$ \\
\hline Pakistan & 0.3400 & $\mathbf{7}$ \\
\hline Afghanistan & 0.1454 & $\mathbf{8}$ \\
\hline
\end{tabular}

Neeraj Narayan is a Research Scholar at Department of Statistics, Banras Hindu University.

Kaushalendra Kumar Singh is Senior Professor at Department of Statistics, Banras Hindu University.

Ujjaval Srivastava is an Indian Statistical Service (Probationer) at National Statistical System Training Academy, Ministry of Statistics \& Programme Implementation, Government of India. Declaration: The views expressed in this paper are his own and not that of Goverenment of India.

Email:neeraj.narayan4@bhu.ac.in 
Sciences Vol. 9 No.1 March 2020 pp. 51-75

\section{Theorizing Beta Thalassemia Major: An Overview of Health Sociology}

Muhammad Abo ul Hassan

Rashid

Shaheed Zulfikar Ali Bhutto

Institute of Science and

Technology
Saif-Ur-Rehman Saif Abbasi

International Islamic University

\section{Abstract}

This research focuses on specific models of health and illness, explored by many researchers across the world. The sequential variations and critic of each model is summed up by researcher and the relevant theoretical orientations of beta thalassemia major have been tried to integrate. Beta thalassemia major is a common genetic disorder, due to abnormalities in human globin (alpha or beta). The highest prevalence rate of disease has been seen in Saudi Arabia, Jordon, India, Bangladesh and Pakistan, due to repeated cousin marriages, strong beliefs of cultural and traditional practices and lack of knowledge for the prevention and management of beta thalassemia major. The focus of epidemiologists remained on genetic causes and ignored the social, cultural, religious and psychological factors which preponderate over biological aspects of health. The academician and health experts lacked to focus the theoretical orientations of beta thalassemia major, this paper elucidates the models of health and illness and provides and logical theoretical itinerary for beta thalassemia major.

Keywords: Beta Thalassemia Major, Sociology, Health, Illness, Bio-psychosocial 
Sciences Vol. 9 No.1 March 2019 pp. 51-75

\section{Teorizando la Beta Talasemia Mayor: Una Visión General de la Sociología de la Salud}

Muhammad Abo ul Hassan

Rashid

Shaheed Zulfikar Ali Bhutto

Institute of Science and

Technology
Saif-Ur-Rehman Saif Abbasi

International Islamic University

\section{Resumen}

Esta investigación se centra en modelos específicos de salud y enfermedad, explorados por muchos investigadores en todo el mundo. El investigador resume las variaciones secuenciales y la crítica de cada modelo y se ha intentado integrar las orientaciones teóricas relevantes de la beta talasemia mayor. La beta talasemia mayor es un trastorno genético común, debido a anormalidades en la globina humana (alfa o beta). La mayor tasa de prevalencia de la enfermedad se ha visto en Arabia Saudita, Jordon, India, Bangladesh y Pakistán, debido a los repetidos matrimonios de primos, las fuertes creencias de las prácticas culturales y tradicionales y la falta de conocimiento para la prevención y el manejo de la beta talasemia mayor. El foco de los epidemiólogos se mantuvo en las causas genéticas e ignoró los factores sociales, culturales, religiosos y psicológicos que prevalecen sobre los aspectos biológicos de la salud. El académico y los expertos en salud carecían de un enfoque en las orientaciones teóricas de la beta talasemia mayor, este documento aclara los modelos de salud y enfermedad y proporciona un itinerario teórico lógico para la beta talasemia mayor.

Palabras clave: refugiados, beta talasemia mayor, sociología, salud, enfermedad, biopsicosocial 


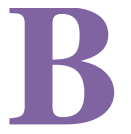

eta Thalassemia Major is a commonly known genetic disorder, which occurs due to the abnormality of beta-globin gene in human body and it transmits from parents to the children by biological means (Galanello \& Origa, 2010). The disease has become a public health problem across the world and especially in traditional and culturally oriented societies (Mufti et al., 2015), because of numerous social, cultural and religious practices such as; consanguinity (Khan et al., 2015), religious restrictions for the management and prevention of disease, lack of knowledge and access to the scientific health management tools (Ghafoor, 2016). It is also evident that due to this genetic disorder; parents, families and thalassemia patients have to face substantial amount of psychological and social estrangements e.g. social isolation, stigmatization, loneliness, weak social interaction, depression, anxiety and pessimism (Khurana et al., 2006).

The scholars and academicians have made enormous efforts to study the etiological and biological aspects of beta thalassemia major (Origa et al., 2005) but there are some theoretical gaps in the context of social, cultural and psychological explanations of the disease which have not been concealed due to lack of theoretical orientation of beta thalassemia major. The present study steered to incorporate the dominant models of health and illness to make a logical and theoretical context of beta thalassemia major in the field of health sociology. The models of health and illness have been reviewed by researchers and their basic explanations, criticisms and relevancies with beta thalassemia major have been tried to be summed up in this research paper.

\section{Beta Thalassemia Major; Evidences from Pakistan}

The number of beta thalassemia major's cases are growing day by day in Pakistan, approximately 5 to 9 thousand thalassemic children born every year (although the registered data is not available) (Hassan et al., 2019). The prevalence of this genetic disorder can be grasped across the world and especially in traditional and culturally dominated societies such as Pakistan, India, Bangladesh, Iran and Saudi Arabia (Hossain et al., 2020). The significant reasons for the higher prevalence of this genetic disorder are 
repeated cousin marriages (Khalid et al., 2019), lack of knowledge and awareness (of couples and families including general masses) regarding prevention of the disease (Naseem et al., 2008) and religious conformity (Arif et al., 2008), which do not allow people to adopt the scientific management practices. The studies conducted in the field of medical and social epistemology ignored the importance of such socio-cultural (knowledge, awareness, consanguinity and endogamy) and religious (false religious beliefs regarding marriage practices, abortion, prevention and management of the disease) aspects of the disease due to absence of conceptual and theoretical connotations, which can articulate these aspects.

\section{Study's Framework}

The present study is a qualitative systematic review of scholarly articles related to "Beta Thalassemia Major" "Sociology of Health and Illness" "Models of Health and Illness" and "Sociological Analysis of Health and Illness". The study aimed to incorporate the theoretical elucidation for beta thalassemia major and for this purpose we reviewed 187 research articles (published during 2000 to 2019). The selection of articles for analysis was initially based on the relevancy of title while, at the second stage the abstracts of selected articles were screened and finally the full articles were included or excluded. The study is based on systematic review of 50 articles, which were fully corroborated for detailed analysis (the statistical techniques or meta-analysis was not applied).

\section{Models of Health and Illness}

The numbers of health models are developed by sociologist, psychologist and health professionals to expose the cause and consequences of health and illness. These theorist and researchers intended to explain social (Hughes \& Paterson, 2006; Shakespeare \& Watson, 1997), cultural (Jegede, 2002; Wong \& King, 2007), psychological and ecological (Coreil, 2010; Murray \& Chamberlain, 1999; Willig, 2000), as well as biomedical explanations of health and illness (Farre \& Rapley, 2017). 
The prominent approaches in the field of health and illness gained a significance influence of biomedical and social vindications. Although these two approaches have significant differences with each other's, in terms of their examination, explanation and interpretation of disease and health. According to World Health Organization, health is defined as a state of being fit and well along with mental reasoning (WHO, 2005). In views of (Blaxter, 2004),

if a person can easily perform his/her daily activities e.g. performing household tasks and managing and participating in social gatherings, the state of robustness reveals he/she is healthy (p.122).

The most commonly found scientific and theoretical constructions of health are listed below.

\section{Biomedical Model of Health and Illness}

From most of the earlier explanations of health and illness, in the field of medical sociology biomedical model is instigator (Alonso, 2004). The model remained highly appreciated and followed by social and medical scientist during 1900s in Western Societies. In the view of biomedical model of health and illness, the complete functioning and malfunctioning of a body depends upon the biological explanations. The estimation of this model suggested that fixing biological issues by treating people through surgeries, using medicines and drugs for different therapies can ensure health and diminish illness (Minaire, 1992). Later on, with the emergence of different environmental, social and psychological explanations of health and illness, this model was criticized by many researchers (Adibi, 2014; Fertonani et al., 2015; Smart, 2006).

In many of the researchers' view, the absence of illness is defined as health (Calnan, 1987; Hughner \& Kleine, 2004; Williams, 1983), however many other lay perceptions have been seen by considering health as a relative phenomenon, that truly depends on the experiences and evaluations made by individuals and considered the state as health or not by means of their age, gender, social status and medical conditions. For those, who 
measured health on these lay perceptions, conceptualized health as only the absence of any physical problems which interfere their daily lives activities (Bury, 2005).

The explanation made by Baggott (2004) about the biomedical model depends on the physical functioning of an individual, if an individual is physically performing well he/she must be considered as healthy and the explanation of bad health can be described as the presence of any disease or illness, resulting physical malfunctioning due to any injury or infection. Biomedical model ignores the social and psychological factors and keep its focus on medical and biological changes which can be measured and defined in isolation. These biological and medical factors are failed to explain the complete state of health or illness because their elucidation depends on dysfunction of the organ or tissue of the body instated of overall condition of the patient (quality of life, wellbeing, adjustment and other social, psychological and mental aspects of health. The core of biomedical model entails a specific etiology e.g. every disease is/can be caused by the germs, bacteria or any kind of parasite (Seale, 2003).

An important illustration about biomedical model is based on its generic nature, which explains that each disease either viral, genetic or by any mean is based on the participles of universalism (Fischer, 2009). The approach ignores the cultural and social explanation and construction of health by believing in the biological agentic nature of health (Farmer et al., 2012). Denigration of this explanation is based on the idea of cultural variations to explain health and illness and the changing definition of any disease with the passage of time. Usually, it can be comprehended that what is seen as illness in any particular societies, at the given period of time, depends on social and cultural contextualization's (Naidoo \& Wills, 2016).

Another approach of biomedicine is supported by the spat of measurable biotic variables and perceived illness; as a deviation from normal range. The psychological abnormalities and impacts are the counter arguments for this explanation because of varying nature of mental and psychological factors of emotional and psychological disorders (Engel, 1978). It is also believed by health sociologists and psychologists that; mental abnormalities and emotional disorders often remain unclear and cannot be generalized on the principles of normality. Medical scientists have realized that human 
behaviors are not universal, and illness or health cannot be perceived universally (Cockerham \& Cockerham, 2014). It has also been realized by many researches of medical sciences, that human organism diverges in terms of structural and functional patterns and even the genetic variations remain unclear (Heylighen, 1999).

Having a strong belief on neutrality and objectivism, medical theories perceived individual as a product of biological progression. According to the biological naturalistic and objectivist; individual have little control over their lives and on the construction of health (Crawford, 2006). In the view of naturalistic and objective orientation of health and illness, as the biomedical model emphasizes, individuals remain unable to construct or contribute in the construction of health or illness (Crawford, 2006). The only explanation of health or illness remains on biological explanations, without considering the social, cultural and psychological causes. The critics have carped this argument of neutrality because there are various dictating forces in terms of social, cultural and political conducts which shape and effect the human health and illness. Being unhealthy could be the result of these (social, political/administrative and cultural) factors and practices (Harley et al., 2011; Williams, 1995).

In contemporary debates of biomedicine and biomedical, it has been acknowledged by health experts and researchers that there are multiple approaches for the interpretation of health and illness, instead of having a robust deem on biological determinism and value of neutrality (Müller, 2019). These multiple approaches include: social and psychological causes, anxiety, depression, cultural practices and different environmental factors (Noar et al., 2008). Current debates have incorporated the multidimensional approaches and their interrelatedness for the explanation and investigation of health and illness (Chenier, 1997). Biomedical model focuses on the quantification and treatment of any particular disease by means of only medications and clinical trials and due to this narrow and reductionist slant, it has been highly criticized by the social and environmental scientists because this approach perceives health as only the absence of any indisposition (Alberts et al., 2014; Engel, 1977). 


\section{Social Model of Health}

After the dominant criticism over the biomedical model in the $21_{\text {st }}$ Century, the literature drew attention of health experts and medical scientists to integrate social causes for the exoneration of health and illness. Social narratives were highlighted the cultural, religious, communal and familial practices, which shape the health of any individual and the practices to avoid ill health. The social conceptions included health and hygiene, marriages practices, psychological aspects and health disparities (Novotný et al., 2018), instead of only focusing on medicines and clinical experiments, which were dominant in earlier model (biomedical model). The social model included the social and cultural variations for the construction of health and explained health as a continuous process of individual, cultural and social practices (Fried et al., 2004). From Weberian explanation of life chances and choices (Cockerham et al., 1993) to sick role of (Parsons, 1951), health and illness have been conceptualized differently across the world (Larson, 1999) and the universal agreement on the definition of health is still debate (Zautra et al., 2010) because the social and cultural practices and understandings are not identical.

The social model interprets biological mechanisms in terms of social causes and constructs health or being unhealthy is based on social explanations. The model contextualizes health as an amalgamation of social factors including socio-economic status, cultural practices, sanitation and hygiene. The proponents of the social model (Anastasiou \& Kauffman, 2011; Ghaemi, 2009) have accentuated to include social aspects e.g. poverty, awareness, parental practices, ethnic and cultural practices and religious beliefs to be cuddled for the understanding of health and illness. Social model also allowed mental and psychological factors to be given share in its core domain because these (mental and psychological) aspects either become causes or consequences of any disease (Kawachi \& Berkman, 2001).

\section{Bio-psychosocial Model}

Another major theoretical and practical contribution by many researchers (Engel, 1978, 1981, 1982) in sociology of health and illness is the bio- 
psychosocial model of health and illness. Bio-psychosocial model is known as the extension of the former model (biomedical). This model is also known as a multi-factorial approach of health and illness because it includes biological, psychological and social aspects, implicated with a patient's health status (Alonso, 2004; Havelka et al., 2009). This multidimensional approach of health and illness is characterized based on:

1. biological factors (genes and chromosomes)

2. behavioral/psychological factors (life styles, stress management practices, health believes etc.)

3. social factors (cultural, religious life histories, social relations and social support etc.).

It includes social, psychological and biological factors that influence health, unlike biomedical model that only theorizes and measures health, illness and practices based on genetic and biological aspects.

\section{Web of Causation}

The major contribution by epidemiologist was to develop the web of causation approach also known as agent host model, which is an epidemiological model of health and illness and views the disease as a result of an intricate set-up of interviewing risk factors between the agents, the host and the environment (Norell, 1984). This model includes the elements of environment such as unhygienic living conditions, pollution, problems of sanitations, contaminated water and food and industrial chemicals which are responsible for spreading the virus of any disease and due to the carless practices and unhygienic living environment, the inhabitant of polluted environment become vulnerable towards unhealth life style. and the individual become recipient for being careless or unaware of health standards (MacMahon et al., 1960). The model emphasizes on healthy environment and precautionary individual's practices by protecting and cleaning their own surroundings. The ideal health standards can be ensuring by avoiding the unhealthy practices, protecting environment and ensuring the standardized practices of quality of life by the individual. 


\section{Ecological model}

The ecological model is derived from the broad field of human ecology, which studies the interrelationship of human interaction, social organization, and the natural environment. It relates the quality of life to the development of ecological resources at a population level, in terms of addressing the environmental impact of urban and rural settlements, industry, technology, and culture. Ecological model of health has a similarity with agent host model, because both include the environment as an element to ensure health state of any individual (Reifsnider et.al., 2005; Salliset al., 2015).

\section{New public health}

The contemporary approach in the field of sociology of health and illness is the emergence of new public health approach (Baum, 1998). This model of health that links the traditional public health concerns of sanitation, hygienic practices, clean air and water with the social, cultural, behavioral and political-economic factors that affect people's health. It directs attention to the prevention of illness trough community participation and social reforms that address living and working conditions. Instead of merely focusing on individual factors, the new public health model indicates a broader range of social, political, historical and economic forces of health's production and distribution (Frenk, 1993). The model focuses on policies and behaviors which changes the health practices of communities (Fielding et al., 2010).

\section{The Limits of Medicine}

Although biomedical model of health and illness significantly contributed in the field of health and illness especially the treatment, causes and prevention of diseases. Whereas, a very significant criticism can be found on biomedical model with reference to the point of view of social and psychological researchers and philosophers. They pointed out that biomedical model ignored social, behavioral and psychological parameters and aspects of health and illness. Neglecting these factors, an individual cannot understand the complexities of health and illness. One of the major 
criticisms on bio-medical, pointed out that, the causation of disease does not always mean the interaction (Dubos, 1987). The prevalence of disease is based on multiple factors, that can be physical, psychological (stress) and related to practices (food and nutrition). Another major criticism on biomedical model is reductionism (Mehta, 2011).

In the view of many researchers (Daniels, 1989; Gifford, 2016), biomedical model focuses on smaller units (e.g. cells, biological organism) and completely ignores the general and holistic aspects such as social and psychological. Reductionism also lead to biological determinism and according to this point of view, determinism and explanation of health and illness is based on the biologically determined factors (chromosomes, hormones and genes), while many aspects of life, such as happiness, psychological and emotional disorders, anxiety, depression and even many genetic disorders are based on social and cultural practices rather than solely depending on biological factors (Germov, 2014).

In sum, biomedical model is highlighted by its nature of victim blaming. As it creates culpability for any sick individual among other members of his/her community by considering the individual a sole cause of his/her disease and ignore all other social facets by which a disease can prevail. Because of many social, economic, religious and cultural practices, attitudes and believes, biomedical model face a very strong criticism by social researchers (Broom \& Adams, 2016; Geist \& Dreyer, 1993; Lyman, 1989). Due to the widespread criticism on biomedical model of health and illness, medical and social researchers developed varieties of new models and frameworks to explain and contextualize health and illness. The significant models in the field of health and illness other than biomedical interpretations include; social model, bio-psychosocial model, web of causation, ecological and new public health model of health and illness. These models significantly highlighted the environmental, social, ecological, cultural and psychological aspects of health and construction of health and illness.

\section{Social Construction of Health and Illness}

Sociology of health and illness seeks to examine the effect of social aspects such as caste, class, ethnicities, marriage patterns, socio-economic status, 
family systems and socio-political conditions on health of any society (Sharf \& Vanderford, 2003). In the discussion of health sociology, sociologists have tried to incorporate the aspects of social pathologies, health seeking behaviours, individual and collective communal practices, to understand any disease (Conrad \& Barker, 2010).

In the view of (Fleming \& Parker, 2015), health or absence of health is not merely the attribute of biological or natural aspects (p. 27), social researches found the contribution of socio-economic status, cultural believes and practices (consanguinity, stigmatization and marriage patterns) and the values (cast system, ethnic preferences etc.) which have a greater influence over the assertion of being healthy or not. In the diverse definitions of Sociology of health (Mattlin, 2018) focused on three major domains in the field of health and illness: the first one is the conceptualization of health, second is the study of measurement and social distribution of health and third is known as the justification of the patterns in health and illness. Furthermore, there is a significant difference between medical sociology (that focuses on epidemiological demeanors, health institutions and dexterities of medical practitioners) and sociology of health and illness (Nettleton, 2006) because sociology of health and illness includes social, cultural, economic and political facets, which influence the health practices, statuses and focus on underlying causes of any disease $(p, 13)$.

Sociology of health and illness swathes the ecological and environmental causes of an illness and attitudes and perceptions on individuals towards the understanding and precautions of any disease. It also focuses on psychological and emotional problems, allied with the jounce of any mental or psychological malady. Unlike studying or researching the specific extent of any disease, sociology of health and illness have a holistic view to study the collective effects and cardinal geneses (social, psychological, cultural, political and emotional) of any scrupulous disease (McKee, 1988). Conceptualization of health and illness varies from the point of view of different schools, the conventional approaches to health and illness focus on biological and behavioural explanations and construction of health and illness (Arber, 1987). However the formation of health and illness is based on many social factors, e.g. class differences, awareness, knowledge, attitudes, perceptions, practices, socio-economic status, gender, race and 
ethnicity (Merrild et al., 2016). Because of all these social aspects, researchers focused to find out the social causes and consequences of many chronic disease and genetic disorders. The individualistic approaches tend to focus on and alter the life styles and practices, which are prone to the propagation of many genetic disorders i.e. thalassemia.

\section{Theoretical Construction of Beta Thalassemia Major}

As identified by (Goffman, 1963), a person becomes stigmatized based on an attribute, that negatively effects his/her social interaction with rest of the community or society (p. 138). In the view of (Goffman, 1986), stigma is classified into three major forms. A first factor is any kind of physical disability of body image while the second explanation of stigma is, any kind of individual characteristic (e.g. mental and psychological abnormality) and lastly, he proposed that tribal factors such as race, gender, cast, religion and ethnicity also endorse stigma.

It has been explored by many researchers (Anum \& Dasti, 2016) that patients and families of thalassemia are usually pilloried, particularly because of tribal factors. Mostly these individuals (patients of thalassemia disease) are called and pronounced as thalassemic (being labeled based on their disease). Social isolation and exclusion from communal activities are hard facts, often faced by the parents and families of sick children due to their disease. In many cases, mothers suffer severe mental and psychological stress and face social pressure due to the illness of their child (Arbabisarjou et al., 2015).

In Pakistan, where the patriarchal family structure is excursed overpoweringly, and women must face a strong level of criticism and stigmatization for giving birth to a child with any genetic disorder like thalassemia. The ideas of victim blaming and self-blaming (Shiloh, 2006) become germane in the context of thalassemia because parents of thalassemic children indict themselves for being the cause of thalassemia (Murphy, 2005).

The application of bio-psychosocial model in thalassemia can interpret the biological factors related to the thalassemia in the context of genetic vulnerability, disability and physical health while social factors includes 
awareness and knowledge about the disease and cultural practices for the understanding and propagation of thalassemia. Reviewing the literature showed that psychological aspects are only measured as impact of thalassemia on patients and their families (Baraz et al., 2016; Behdani et al., 2015; Mansoor et al., 2018), however genetic abnormalities (Brancaleoni et al., 2016; de Dreuzy et al., 2016) and socio-cultural factors (Sarvestani et al., 2019; Seyedifar et al., 2016) are the major risk factors of thalassemia propagation.

\section{Sociological Analysis of Beta Thalassemia Major}

Over the period, medical sociology morphed into the specific discipline known as sociology of health and illness and social scientists considered medicines too restrictive as an indicator of the sociological interest in health realm (Bloom et al., 2002; Conrad, 2008). A shift in the field of medicines and then into medical sociology can be seen by the critics on epidemiologist and medical sociologist who were researching and analyzing health and illness on solely clinical parameters. Ignoring social, psychological and cultural factors allied with health and illness caused seriousness in failure of finding the risk factors and basis of many chronic genetic disorders, including thalassemia. The remarkable efforts of social scientists in determining the social factors as underpinning with health and illness develop independent discipline-Sociology of Health and Illness.

Perceiving health and illness with perspective of sociology became more distinctive after the contribution of American Sociologist Charles Wright Mills (1916-62), who used a very idiosyncratic term "Sociological Imagination" to describe any social aspect of human life with the lens of sociology. This method provides an in-depth and a very comprehensive understanding of social life. The perspective enables us to understand social problems, their possible causes and proposed solution to avoid future incongruities. Whereas thalassemia as a major public health problem across the globe and particularly in Pakistan, required social understanding, remedies and solution rather than focusing on biomedical, because it has more to deal with social aspects of life. 
The Australian sociologist Evan Willis suggests that the sociological imagination consists of four interrelated parts. The intension, to apply these aspects to gain understanding of thalassemia as a public health problem, existing across the world can be traced and explored with the lens of sociology (Willis, 1993).

1. Historical factors: How the past influences the present (family history of the patients and inheritance leads to the higher propagation of thalassemia)

2. Cultural factors: How culture impacts on our lives (consanguinity, religiousity, stigmatization and termination of pregnancy)

3. Structural factors: How particular forms of social organization affect our lives (treatment cost, hospital expenditures, blood transfusion)

4. Critical factors: How we can improve our social environment (awareness level of the respondents about prenatal and post marriage screening, knowledge about the disease and its preventive measures can reduce the prevailing condition of thalassemia across the world and especially in Pakistan)

\section{Conclusion}

Beta thalassemia major is a prevailing public health problem across the world and especially in developing countries. The prominent social factors (lack of knowledge and awareness about prevention and management of the disease, denial of pre/postnatal screening practices and genetic counselling), cultural factors (consanguinities, ethnic preferences for marriage, blind religious beliefs and role of patriarchy) propagates this genetic ailment. The disease pretense a strong psychological and social impact on the families, parents and sick children. The biological explanations (abnormalities in hemoglobin) are prime causes but the generic nature of social, cultural and religious aspects also required an academic deportment to be incorporated, while researching beta thalassemia major. Due to lack of theoretical orientations, researchers left leaved gray areas for suggesting theoretical construction of beta thalassemia major. With this aim, the present study includes bio-psychosocial model as a theoretical framework to identify the 
social, cultural, economic and disease allied risk factors of beta thalassemia major, while the psychological factors are considered as an impact on patients and their families because these factors do not prompt thalassemia, yet impose a significant effect on quality of life, social adjustment and wellbeing of parents and patients. It is also evident that even though the social and psychological narrations have been widely accepted by the researches and experts but still there is a debate and a negative argument prevails against these psychosocial explanations of health and illness.

\section{References}

Adibi, H. (2014). Health: Its Implications within the Biomedical and Social Models of Health-a Critical Review. Cyber Journals: Multidisciplinary Journals of Science and Technology, 4(2), 16-23. Alberts, B., Kirschner, M. W., Tilghman, S., \& Varmus, H. (2014). Rescuing US biomedical research from its systemic flaws. Proceedings of the National Academy of Sciences, 111(16), 57735777. http://doi.org/10.1073/pnas.1404402111

Alonso, Y. (2004). The biopsychosocial model in medical research: the evolution of the health concept over the last two decades. Patient Education and Counseling, 53(2), 239-244. http://doi.org/10.1016/S0738-3991(03)00146-0

Anastasiou, D., \& Kauffman, J. M. (2011). A social constructionist approach to disability: Implications for special education. Exceptional Children, 77(3), 367-384. http://doi.org/10.1177/001440291107700307

Anum, J., \& Dasti, R. (2016). Caregiver burden, spirituality, and psychological well-being of parents having children with thalassemia. Journal of Religion and Health, 55(3), 941-955. http://doi.org/10.1007/s10943-015-0127-1

Arbabisarjou, A., Karimzaei, T., \& Jamalzaei, A. (2015). The perception of Biological experience in patients with major thalassemia: A qualitative research. Global Journal of Health Science, 7(1), 79. http://doi.org/10.5539/gjhs.v7n1p79 
Arber, S. (1987). Social class, non-employment, and chronic illness: continuing the inequalities in health debate. British Medical Journal (Clinical Research ed.), 294(6579), 1069-1073. http://doi.org/10.1136/bmj.294.6579.1069

Arif, F., Fayyaz, J., \& Hamid, A. (2008). Awareness among parents of children with thalassemia major. The Journal of the Pakistan Medical Association, 58(11), 621-624.

Baraz, S., Miladinia, M., \& Mosavinouri, E. (2016). A comparison of quality of life between adolescences with beta thalassemia major and their healthy peers. International Journal of Pediatrics, 4(1), 1195-1204. http://doi.org/10.22038/IJP.2016.6228

Baum, F. (1998). The new public health: an Australian perspective. Oxford University Press.

Behdani, F., Badiee, Z., Hebrani, P., Moharreri, F., Badiee, A. H., Hajivosugh, N., Rostami, Z., Akhavanrezayat, A. (2015). Psychological aspects in children and adolescents with major thalassemia: A case-control study. Iranian Journal of Pediatrics, 25(3). http://doi.org/10.5812/ijp.25(3)2015.322

Blaxter, M. (2004). Health. Cambridge Polity Press.

Bloom, J. R., Hu, T. w., Wallace, N., Cuffel, B., Hausman, J. W., Sheu, M. L., \& Scheffler, R. (2002). Mental health costs and access under alternative capitation systems in Colorado. Health Services Research, 37(2), 315-340. http://doi.org/10.1111/1475-6773.025

Brancaleoni, V., Di Pierro, E., Motta, I., \& Cappellini, M. (2016). Laboratory diagnosis of thalassemia. International Journal of Laboratory Hematology, 38, 32-40. http://doi.org/10.1111/ijlh.12527

Broom, A., \& Adams, J. (2016). A critical social science of evidence-based healthcare. In A. Broom \& J. Adams (Eds.), Evidence-based healthcare in context. Critical social sciences perspective (pp. 15-34). Routledge.

Bury, M. (2005). Postmodernity and health. In G. Scambler \& P. Higgs (Eds.), Modernity, medicine and health. Medical Sociology towards 2000 (pp. 19-46). Routledge.

Calnan, M. (1987). Health and illness. The lay perspecctive. Tavistock Publications. 
Chenier, M. C. (1997). Review and analysis of caregiver burden and nursing home placement: the multiple problems and variables affecting the caregiving relationships require multiple approaches and interventions. Geriatric Nursing, 18(3), 121-126. http://doi.org/10.1016/s0197-4572(97)90029-X

Cockerham, W. C., Abel, T., \& Lüschen, G. (1993). Max Weber, formal rationality, and health lifestyles. Sociological Quarterly, 34(3), 413425. http://doi.org/10.1111/j.1533-8525.1993.tb00119.x

Cockerham, W. C., \& Cockerham, G. B. (2014). Health and globalization. The Wiley Blackwell Encyclopedia of Health, Illness, Behavior, and Society, 954-972.

Conrad, P. (2008). The sociology of health and illness. Worth Publishers.

Conrad, P., \& Barker, K. K. (2010). The social construction of illness: Key insights and policy implications. Journal of Health and Social Behavior, 51(1_suppl), S67-S79. http://doi.org/10.1177/0022146510383495

Coreil, J. (2010). Social and behavioral foundations of public health. Sage.

Crawford, R. (2006). Health as a meaningful social practice. Health: An Interdisciiplinary Journal for the Study of Health, Illness, and Medicine, 10(4), 401-420. http://doi.org/10.1177/1363459306067310

Daniels, N. (1989). The biomedical model and just health care: Reply to Jecker. The Journal of Medicine and Philosophy, 14(6), 677-680. http://doi.org/10.1093/jmp/14.6.677

de Dreuzy, E., Bhukhai, K., Leboulch, P., \& Payen, E. (2016). Current and future alternative therapies for beta-thalassemia major. Biomedical Journal, 39(1), 24-38. http://doi.org/10.1016/j.bj.2015.10.001

Dubos, R. J. (1987). Mirage of health: utopias, progress and biological change. Rutgers University Press.

Engel, G. L. (1977). The need for a new medical model: a challenge for biomedicine.

Science, 196(4286),

129-136. http://doi.org/10.1126/science.847460

Engel, G. L. (1978). The biopsychosocial model and the education of health professionals. Annals of the New York Academy of Sciences, 310(1), 169-181. http://doi.org/10.1111/j.1749-6632.1978.tb22070.x 
Engel, G. L. (1981). The clinical application of the biopsychosocial model. The Journal of Medicine and Philosophy: A Forum for Bioethics and Philosophy of Medicine.

Engel, G. L. (1982). The biopsychosocial model and medical education: who are to be the teachers? The New England Journal of Medicine, 306, 802-805. http://doi.org/10.1056/NEJM198204013061311

Farmer, J., Bourke, L., Taylor, J., Marley, J. V., Reid, J., Bracksley, S., \& Johnson, N. (2012). Culture and rural health. Australian Journal of Rural Health, 20(5), 243-247. http://doi.org/10.1111/j.14401584.2012.01304.x

Farre, A., \& Rapley, T. (2017). The New Old (and Old New) Medical Model: Four Decades Navigating the Biomedical and Psychosocial Understandings of Health and Illness. Healthcare (Basel, Switzerland), 5(4), 88. https://doi.org/10.3390/healthcare5040088

Fertonani, H. P., de Pires, D. E. P., Biff, D., \& dos Anjos Scherer, M. D. (2015). The health care model: concepts and challenges for primary health care in Brazil. Ciencia \& Saude Coletiva, 20(6), 1869-1878. http://doi.org/10.1590/1413-81232015206.13272014

Fielding, J. E., Teutsch, S., \& Breslow, L. (2010). A framework for public health in the United States. Public Health Reviews, 32(1), 174. http://doi.org/10.1007/BF03391597

Fischer, M. M. (2009). Anthropological futures. Duke University Press.

Fleming, M. L., \& Parker, E. (2015). Introduction to Public Health eBook. Elsevier Health Sciences.

Frenk, J. (1993). The new public health. Annual Review of Public Health, 14(1), 469-490. http://doi.org/10.1146/annurev.pu.14.050193.002345

Fried, L. P., Carlson, M. C., Freedman, M., Frick, K. D., Glass, T. A., Hill, J., McGill, S., Rebok, G. W., Seeman, T., Tielsch, J., Wasik, B. A., \& Zeger, S. (2004). A social model for health promotion for an aging population: initial evidence on the Experience Corps model. Journal of Urban Health, 81(1), 64-78. http://doi.org/10.1093/jurban/jth094

Galanello, R., \& Origa, R. (2010). Beta-thalassemia. Orphanet Journal of Rare Diseases, 5(1), 11. http://doi.org/10.1186/1750-1172-5-11

Geist, P., \& Dreyer, J. (1993). The demise of dialogue: A critique of medical encounter ideology. http://doi.org/10.1080/10570319309374446 
Germov, J. (2014). Second opinion: an introduction to health sociology. Oxford University Press.

Ghaemi, S. N. (2009). The rise and fall of the biopsychosocial model. The British Journal of Psychiatry, 195(1), 3-4. http://doi.org/10.1192/bjp.bp.109.063859

Ghafoor, M. B. (2016). Level of awareness about thalassemia among parents of thalassaemic children. Journal of Rawalpindi Medical College, 20(3), 209-211.

Gifford, F. (2016). The Biomedical Model and the Biopsychosocial Model in Medicine. In M. Solomon, J. R. Simon \& H. Kincaid (Eds.), The Routledge Companion to Philosophy of Medicine (pp. 459-468). Routledge.

Goffman, E. (1963). Stigma. Notes on the Management of Spoiled Identity. Penguin.

Goffman, E. (1986). Stigma: notes on the management of spoiled identity. Touchstone.

Harley, K., Willis, K., Gabe, J., Short, S. D., Collyer, F., Natalier, K., \& Calnan, M. (2011). Constructing health consumers: Private health insurance discourses in Australia and the United Kingdom. Health Sociology Review, 20(3), 306-320. http://doi.org/10.5172/hesr.2011.20.3.306

Hassan, J., Nadeem, M., Ansari, S. H., Ahmed, S., Parveen, S., \& Shamsi, T. (2019). Frequency of Alpha Thalassaemia in homozygous Beta Thalassaemia paediatric patients and its clinical impact at a blood disease centre in Karachi, Pakistan. JPMA, 69(959).

Havelka, M., Despot Lučanin, J., \& Lučanin, D. (2009). Biopsychosocial model-the integrated approach to health and disease. Collegium Antropologicum, 33(1), 303-310.

Heylighen, F. (1999). The growth of structural and functional complexity during evolution. In F. Heylighen, J. Bollen \& A. Riegler (Eds.), The evolution of complexity (pp. 17-44). Kluwer Academic.

Hossain, M. S., Hasan, M. M., Raheem, E., Islam, M. S., Al Mosabbir, A., Petrou, M., \& Siddiqee, M. H. (2020). Lack of knowledge and misperceptions about thalassaemia among college students in 
Bangladesh: a cross-sectional baseline study. Orphanet Journal of Rare Diseases, 15(1), 1-10. http://doi.org/10.1186/s13023-020-1323-y Hughes, B., \& Paterson, K. (2006). The social model of disability and the disappearing body: Towards a sociology of impairment. In L. Barton (Ed.), Overcoming disabling barriers. 18 years of disability and society (pp. 101-117). Routledge.

Hughner, R. S., \& Kleine, S. S. (2004). Views of health in the lay sector: A compilation and review of how individuals think about health. Health: An Interdisciiplinary Journal for the Study of Health, Illness, and Medicine, 8(4), 395-422. http://doi.org/10.1177/1363459304045696

Jegede, A. S. (2002). The Yoruba cultural construction of health and illness. Nordic Journal of African Studies, 11(3), 14-14.

Kawachi, I., \& Berkman, L. F. (2001). Social ties and mental health. Journal of Urban Health, 78(3), 458-467. http://doi.org/10.1093/jurban/78.3.458

Khan, M. S., Ahmed, M., Khan, R. A., Mushtaq, N., \& Shah, M. W. U. (2015). Consanguinity ratio in b-thalassemia major patients in District Bannu. The Journal of the Pakistan Medical Association, 65(11), 1161-1163.

Khalid, N., Noreen, K., Qureshi, F. M., \& Mahesar, M. (2019). Knowledge of thalassemia and consanguinity: A multicenter hospital based retrospective cohort study from metropolitan city of Karachi, Pakistan. The Professional Medical Journal, 26(09), 1580-1586. http://doi.org/10.29309/TPMJ/2019.26.09.168

Khurana, A., Katyal, S., \& Marwaha, R. K. (2006). Psychosocial burden in thalassemia. The Indian Journal of Pediatrics, 73(10), 877-880. http://doi.org/10.1007/BF02859278

Larson, J. S. (1999). The conceptualization of health. Medical Care Research and Review, 56(2), 123-136. http://doi.org/10.1177/107755879905600201

Lyman, K. A. (1989). Bringing the social back in: A critique of the biomedicalization of dementia. The Gerontologist, 29(5), 597-605. http://doi.org/10.1093/geront/29.5.597

MacMahon, B., Pugh, T. F., \& Ipsen, J. (1960). Epidemiologie Methods. J \& A. Churchill Ltd. 
Mansoor, S., Othman, Z., Othman, A., \& Husain, M. (2018). A Descriptive Study on Quality of Life among Adolescents with Beta-Thalassemia Major in the Maldives. International Medical Journal, 25(4), 211214. http://doi.org/10.5281/zenodo.2588035

Mattlin, M. (2018). Examining the Social Construction of Health, Illness, and Wellness in Anti-science Communities. Non published thesis, defended at Vanderbilt University.

McKee, J. (1988). Holistic health and the critique of Western medicine. Social Science \& Medicine, 26(8), 775-784. http://doi.org/10.1016/0277-9536(88)90171-2

Mehta, N. (2011). Mind-body dualism: A critique from a health perspective. Mens Sana Monographs, 9(1), 202. http://doi.org/10.4103/09731229.77436

Merrild, C. H., Vedsted, P., \& Andersen, R. S. (2016). Situating Social Differences in Health and Illness Practices. Perspectives in Biology and Medicine, 59(4), 547-561. http://doi.org/10.1353/pbm.2016.0047

Minaire, P. (1992). Disease, illness and health: theoretical models of the disablement process. Bulletin of the World Health Organization, $70(3), 373$.

Müller, R. (2019). A task that remains before us: Reconsidering inheritance as a biosocial phenomenon. Seminars in Cell \& Developmental Biology.

Murphy, R. (2005). Health professionals and ethnic Pakistanis in Britain: risk, thalassaemia and audit culture. Thesis defended at University of St Andrews.

Murray, M., \& Chamberlain, K. (1999). Qualitative health psychology: Theories and methods. Sage.

Naidoo, J., \& Wills, J. (2016). Foundations for Health Promotion-E-Book. Elsevier Health Sciences.

Naseem, S., Ahmed, S., \& Vahidy, F. (2008). Impediments to prenatal diagnosis for beta thalassaemia: experiences from Pakistan. Prenatal Diagnosis, 28(12), 1116-1118. http://doi.org/10.1002/pd.2133

Nettleton, S. (2006). The sociology of health and illness. Cambridge Polity Press. 
Noar, S. M., Chabot, M., \& Zimmerman, R. S. (2008). Applying health behavior theory to multiple behavior change: considerations and approaches. Preventive Medicine, 46(3), 275-280. http://doi.org/10.1016/j.ypmed.2007.08.001

Norell, S. (1984). Models of causation in epidemiology. In L. Nordenfelt, B. Ingemar \& B. Lindahl (Eds.), Health, Disease, and Causal Explanations in Medicine (pp. 129-135). Springer.

Novotný, J., Ficek, F., Hill, J. K., \& Kumar, A. (2018). Social determinants of environmental health: a case of sanitation in rural Jharkhand. Science of The Total Environment, 643, 762-774. http://doi.org/10.1016/j.scitotenv.2018.06.239

Mufti, G. E. R., Towell, T., \& Cartwright, T. (2015). Pakistani children's experiences of growing up with beta-thalassemia major. Qualitative Health Research, 25(3), 386-396. http://doi.org/10.1177/1049732314552663

Origa, R., Fiumana, E., Gamberini, M. R., Armari, S., Mottes, M., Sangalli, A., \& Borgna-Pignatti, C. (2005). Osteoporosis in $\beta$-thalassemia: clinical and genetic aspects. Annals of the New York Academy of Sciences, 1054(1), 451-456. http://doi.org/10.1196/annals.1345.051

Parsons, T. (1951). Illness and the role of the physician: A sociological perspective. American Journal of Orthopsychiatry, 21(3), 452-460. http://doi.org/10.1111/j.1939-0025.1951.tb00003.x

Reifsnider, E., Gallagher, M., \& Forgione, B. (2005). Using ecological models in research on health disparities. Journal of Professional Nursing, 21(4), 216-222. http://doi.org/10.1016/j.profnurs.2005.05.006

Sallis, J. F., Owen, N., \& Fisher, E. (2015). Ecological models of health behavior. In K. Glanz, B. K. Rimer \& K. Viswanath (Eds.), Health Behavior: Theory, Research, and Practice (pp. 43-64). San Francisco: Jossey-Bass.

Sarvestani, K. A., Hasanifar, A., \& Bagheri, R. (2019). Some Determinants of Contraceptive Use Among Women of Reproductive Age Who Have Children with Thalassemia Major in Sistan and Baluchestan Province, Iran. Women Health Bulletin, 6(2), e90092. http://doi.org/10.5812/whb.90092 
Seale, C. (2003). Health and media: an overview. Sociology of health \& illness, 25(6), 513-531. http://doi.org/10.1111/1467-9566.t01-1-00356 Seyedifar, M., Dorkoosh, F. A., Hamidieh, A. A., Naderi, M., Karami, H., Karimi, M., Fadaiyraryeny, M., Musavi, M., Ahmadian-Attari, M. M., Hadjibabaie, M., Cheraghli, A. M., \& Akbari, S. A. (2016). Healthrelated quality of life and health utility values in beta thalassemia major patients receiving different types of iron chelators in Iran. International Journal of Hematology-Oncology and Stem Cell Research, 10(4), 224-231.

Shakespeare, T., \& Watson, N. (1997). Defending the social model.

Disability \& Society, 293-300. http://doi.org/10.1080/09687599727380

Sharf, B. F., \& Vanderford, M. L. (2003). Illness narratives and the social construction of health. In T. L. Thompson, R. Parrott \& J. F. Nussbaum (Eds.), The Routledge handbook of health communication (pp. 23-48). Routledge.

Smart, J. (2006). Challenges to the biomedical model of disability. Advances in Medical Psychotherapy \& Psychodiagnosis, 12, 1-4.

World Health Organization (2005). Global tuberculosis control: surveillance, planning, financing-WHO report 2005. World Health Organization.

Williams, R. (1983). Concepts of health: an analysis of lay logic. Sociology, 17(2), 185-205. http://doi.org/10.1177/0038038583017002003

Williams, S. J. (1995). Theorising class, health and lifestyles: can Bourdieu help us? Sociology of Health \& Illness, 17(5), 577-604. http://doi.org/10.1111/1467-9566.ep10932093

Willig, C. (2000). A discourse-dynamic approach to the study of subjectivity in health psychology. Theory \& Psychology, 10(4), 547-570. http://doi.org/10.1177/0959354300104006

Willis, E. (1993). The historical sociology of healthcare Health Research in Practice (pp. 97-111): Springer. https://doi.org/10.1007/978-1-48994497-9_7

Wong, N., \& King, T. (2007). The cultural construction of risk understandings through illness narratives. Journal of Consumer Research, 34(5), 579-594. http://doi.org/10.1086/520078 
Zautra, A. J., Hall, J. S., \& Murray, K. E. (2010). A new definition of health for people and communities. Handbook of adult resilience, 1 .

Muhammad Abo ul Hassan Rashid is faculty member of Shaheed

Zulfikar Ali Bhutto Institute of Science and Technology and PhD scholar at the International Islamic University, Pakistan.

Saif-Ur-Rehman Saif Abbasi, is Professor of Sociology at the International Islamic University, Pakistan.

Email: hassan.rashid@szabist-isb.edu.pk 
Sciences Vol. 9 No.1 March 2020 pp.76-102

\section{From Global North-South Divide to Sustainability: Shifting Policy Frameworks for International Development and Education1}

Shalini Singh

Julius Maximilians University of Würzburg

\section{Abstract}

Education policies are becoming increasingly oriented towards employability (economic returns) and subjected to measurements especially post-2015. Despite resistance from different stakeholders, employability has become a global norm and funds for programmes with non-economic objectives, especially in low and middleincome countries have been cut tremendously (Singh \& Ehlers, 2020). Is this a short term crisis, a faulty and confused policy decision, or a part of a long term policy agenda aimed at bigger changes with deeper policy linkages? Who is promoting it with what intentions? How should the actors in the education sector deal with it? This paper answers these questions by mapping and analysing the shift in policy framework for International Development from Global North-South Divide (1970s2015 ) to Sustainability (2015 onwards) and its impact on the policy of education for development. It shows how International Organisations (IOs) used knowledge, information and policy linkages to gain control over states and UN created a narrative about sustainability rooted in environment to facilitate an obscure OECD agenda for sustainable economic growth, backed by World Bank and the IMF's measurement and control tactics. It further explains how and why the development policies (reflected in education) of low, middle and high income countries converged post-2015.

Keywords: sustainable development, policy framework, international organisations, global North-South divide, education for development 


\section{De la División Global Norte-Sur a la Sostenibilidad: Marcos Políticos Cambiantes para el Desarrollo Internacional y la Educación1}

Shalini Singh

Julius Maximilians University of Würzburg

\section{Resumen}

Las políticas educativas se orientan cada vez más hacia la empleabilidad (rentabilidad económica) y son evaluadas, especialmente después de 2015. La empleabilidad se ha convertido en una norma global. Los fondos para programas con objetivos no económicos, especialmente en países de bajos y medianos ingresos, se han reducido enormemente (Singh y Ehlers, 2020). ¿Se trata de una crisis a corto plazo, una decisión política defectuosa y confusa, o parte de una agenda política a largo plazo dirigida a cambios más grandes con vínculos políticos más profundos? ¿Quién lo promociona con qué intenciones? ¿Cómo deberían tratarlo los actores del sector educativo? El artículo responde a estas preguntas analizando el cambio en el marco de políticas para el Desarrollo Internacional de la División Global Norte-Sur (1970- 2015) a la Sostenibilidad y su impacto en la política de educación para el desarrollo. Muestra cómo las Organizaciones Internacionales usaron los vínculos de conocimiento, información y políticas para obtener el control sobre los estados y la ONU creó una narrativa sobre la sostenibilidad enraizada en el medio ambiente para facilitar una oscura agenda de la OCDE para el crecimiento económico sostenible, respaldada por el Banco Mundial y las medidas y control del FMI. Explica además cómo y por qué las políticas de desarrollo (reflejadas en la educación) de los países de bajos, medianos y altos ingresos convergieron después de 2015.

Palabras clave: desarollo sostenible, marco político, organizaciones internacionales, división global norte-sur, educación para el desarrollo 
I

n 2015, seventeen Sustainable Development Goals (SDGs) replaced eight Millennium Development Goals (MDGs) as objectives for as Goal 4 in the SDGs. However, the mentioned change was not merely a change in the policy on International Development but rather a shift in the entire framework within which the policy was embedded. The earlier policy was embedded in the Global North-South Divide Framework while the post2015 policy is embedded in the Sustainability Framework. This implied that transnational, national and sub-national stakeholders were now supposed to operate in a context shaped by the sustainability agenda and follow the corresponding guidelines. This paper analyses the shift from the Global North-South Divide Framework to the Sustainability Framework in 2015 and discusses its relevance for different stakeholders (in general) in relation to Education for Development policy as a consequence of its linkages to the policy on International Development.

Since 1989, the policy frameworks for International Development (including Education for Development) have been shaped primarily by the OECD, the World Bank Group and International Monetary Fund (WB/IMF), the UN and its supporting agencies, and the ILO. ILO recommendations have formed the basis of major work-related, vocational, and employability policies and strategies like Recognition of Prior Learning in countries such as India (OECD, World Bank \& ILO, 2016; Singh \& Ehlers, 2019). The ILO has accepted allegiance to the international agenda for education aiming at development (ILO, n.d.). While the OECD has strong influence in highincome countries, the WB/IMF, and the UN along with its agencies have strong influence in low and middle-income countries outside Europe2. Therefore, this paper analyses documents from the OECD, the WB/IMF, and the UN and its supporting agencies as the primary sources using document analysis. Since ILO's policies focus on labour and work rather than education (ILO, n.d.), ILO policy documents have not been found relevant, and thus not included in this paper.

The policies on different areas of international development were embedded in the Global North-South Divide since the 1970s (Ehrlich, 1980). In 1989, they started converging as a single policy on International Development (including Education for Development), later manifested as 
the MDGs in 2001, and continued to be so till 2015 (Singh, 2018). In 2015, a shift in policy framework was marked by the adoption of SDGs. This paper thus maps global policy changes between 1989 and 2015 relevant in relation to education policies and mentions pertinent facts from the period before and after wherever required.

The research questions include: how has a shift in policy framework for policies on International Development been reflected in Education for Development policies? How is this change relevant for transnational, national and sub-national stakeholders in the context of International Development in general and Education for Development in particular?

The paper is divided into seven sections. The first section (introduction) explains the relevance of discussing the shift in policy framework to understand its relevance for different types of transnational (like transnational education networks), national (like ministries) and sub-national (like universities and researchers) stakeholders in relation to Education for Development policy, mentions the research questions and gives an overview about the methodology. In the second section, an operational definition of policy framework is formulated by comparing it with related concepts of policy norm and policy regime. In the next three sections, the content (for instance terms used, arguments, changes, references etc.) as well as contextual considerations (which IO has published what, when, where, for whom, why and how) of all published policy documents from the mentioned IO between 1945 to 2019 have been analysed and mapped both chronologically as well as thematically using the technique of document analysis to show how the UN and its supporting agencies have been legitimising the OECD agenda for sustainable economic growth in international development and the WB agenda in education policies by constructing illusions of public discussions, summits, committees and negotiations amid low and middle-income countries. However, in order to maintain precision, only those documents are mentioned in the text which were found relevant to answer the research questions directly. In the sixth section the relevance of the shift in policy framework for transnational, national and sub-national stakeholders is discussed followed by the conclusion in the last section. 


\section{Structuring Policies: Norms, Regimes and Frameworks}

A framework is defined by the Cambridge Dictionary (n.d.) as "a supporting structure around which something can be built" or "a system of rules, ideas, or beliefs that is used to plan or decide something". A policy framework can thus be defined as a basic structure (could be assumptive) around which policies are built. It comprises of rules, ideas, and/or beliefs that underlie policies dealing with a certain policy concern (Sabatier, 2007). Policy goals often indicate the framework within which a particular policy is formulated but the framework is not necessarily limited to goals. A policy framework should not be confused with a policy norm or a policy regime. A policy norm is a standard, usually measurable (for instance through an indicator) (Björkdahl, 2002). For instance, the indicator of access to education measures certain aspects of the policy norm considering education as a human right. A regime is a strong structure with rules and regulations, sometimes laws, that might have consequences, if violated (Wilson, 2000). For instance, violation of trade laws negotiated through the World Trade Organisation regarding teaching as a service might attract consequences if violated as they are a part of the global trade regime, consolidated using international laws. Policy framework is a rather loose structure. Unlike a regime, it is based on loose guidelines and therefore, has space for free negotiations (with or without the exercise of influence). Formulating policies outside it may not lead to violation of laws. A framework usually prioritises the concerns of stakeholders and aligns them, clarifies the key terminology at a particular point of time and provides space and directions for negotiations, usually according to the preferences of the most influential actors. Thus, it fixes a point of departure and sets the rules of the game where the game refers to the act of exerting influence by stakeholders during policy negotiations.

\section{The Global North-South Divide Framework and International Development Policies}

The term Global North-South Divide is a geo-political representation of the unequal economic development across the globe. It is rooted in the post 
WW-II era and remained a predominant policy framework in relation to policies on International Development between 1970s and 2015 (Singh, 2018). The imagery of the global North and the global South was strengthened by post-colonial politics, Cold War, Non-Alignment Movement, demands for economic restructuring by low and middle income countries following the oil crisis in the 1970s and the like (Ehrlich, 1980). The countries located in the Northern hemisphere were usually rich, technologically advanced, powerful and industrialised, and former imperialists whereas the countries located in the Southern hemisphere (except for some like Australia and Japan) were former colonies, poor, relied on primary and traditional economy, and had limited international political influence (Ehrlich, 1980; Singh, 2018). The dividing line between the North and the South was sometimes called the "poverty curtain" (Haq, 1976; Escobar, 1995 in Thérien 1999). In 1980, the Independent Commission on International Development Issues (Brandt Commission), appointed at the WB's initiative, made an imaginary line (the Brandt Line) representing the North and the South to acknowledge poverty and unequal development between the two parts of the globe with some exceptions (Independent Commission on International Development Issues, 1980).

States were the primary actors in devising international policies using international platforms to ease their interaction and ensure consolidated intervention wherever needed. Most resources for development came from states. IOs had thus, a limited role to play, shaped by the funding provided primarily by the states. These organisations even competed with each other for influence and the resources that followed it3. For instance, in late 1960s, the NATO and the OECD competed for promoting the idea of addressing environmental concerns in relation to economic growth (Schmelzer, 2016).

The oil crisis and the oil glut in the 1970s forced many countries from the South to seek loans from the WB (Heyneman, 2012). With US backing (Baker Plan, 1985), the WB offered Structural Adjustment Programs (SAPs) to these countries (Heyneman, 2012). These SAPs were integrated policy packages covering almost all policy areas, negotiated between the WB and the finance ministries (irrespective of the protests by other ministries) of the loan-seeking countries (Heyneman, 2012). This made the WB a major policy actor in the global South influencing not only development, but all policies 


\section{Shalini Singh - From Global North-South Divide to Sustainability}

including education. The end of the Cold War, rise of the US as a global hegemon and the EU's internal market, all contributed to an atmosphere where peaceful economic competition (rather than war) could be managed through regulations (Singh, 2018).

The WB-led policy integration was followed by policy convergence between 1989 and 2001. All policies related to development were included in a single policy on International Development. Even though the UN claimed to facilitate this convergence through various conferences (See Figure 1), sources reveal that it presented a distorted picture of reality. Convergence was not planned till 1995 and the OECD planned the convergence since 1995 for economic reasons4. Following the Copenhagen Declaration, 1995 which brought together economic, social and environmental issues, the OECD proposed International Development Goals, 1996 to make policy convergence a reality (Hulme, 2009). Later these goals were adopted as MDGs in 2001 with cosmetic changes as targets for development to be achieved till 2015 (Hulme, 2009; Singh, 2018). When policies converged, IOs started cooperating and aligning their roles with each other (Singh, 2018).

Most policy negotiations remained hierarchical as states negotiated on inter-national policy platforms. The engagement of the South (aid recipients) was limited since apart from other reasons, funding came from the North (aid-donors). Outcomes were measured in terms of aid effectiveness or the amount of aid resources spent on a particular initiative (OECD, 2013). In most cases it meant ensuring the achievement of goals laid in the beginning of each initiative (OECD, 2013). The OECD also led the development of an implementation machinery for policy consolidation by 2008 through development financing and measurement (OECD, 2008; UN 2009).

As the financial crisis aggravated in 2008, huge influx of immigrants, demographic challenges, restructuring of economic patterns and the like, lead to pockets of poverty in the North (OECD, 2012). In contrast, rising living standards, demographic dividends, booming economies and the like lead to pockets of affluence in the South (OECD, 2012). The OECD thus argued for dropping the North-South Framework in 2012, claiming that the divide between the North and the South was no more a reality since 
development challenges needed to be addressed all over the globe (OECD, 2012). However, a mapping of documents reveals that the financial crisis and other reasons only served as windows of opportunitys while a new policy framework was already taking shape as an undercurrent since long6.

Figure 1.

Global Conferences and Summits at the UN Platform leading to Policy Convergence in International Development

\begin{tabular}{lc}
\hline \multicolumn{2}{c}{ Global Conferences and Summits } \\
\hline \multicolumn{2}{c}{ Event } \\
\hline Children & 1990,2002 \\
Education for All & 1990,2000 \\
Least Developed Countries & 1990,2001 \\
Drug problem & 1990,1998 \\
Food Security & 1992,1996 \\
Sustainable Development & 1992,2002 \\
Human Rights & 1993,2001 \\
Population and Development & 1994 \\
Small Island Developing States & 1994,2005 \\
Natural Disaster Reduction & 1994,2005 \\
Women & 1995,2005 \\
Social Development & 1995,2005 \\
Human Settlements & 1996,2001 \\
Youth & 1998 \\
Millennium Summit & 2000,2005 \\
HIV/AIDS & 2001 \\
Financing and Development & 2002 \\
Ageing & 2002 \\
Landlocked and Transit & 2003 \\
Developing Countries & \\
Information Society & 2003,2005 \\
\hline
\end{tabular}

Source: From UN (2007). Copyright 2007 by UN

Till 2015, the entire policy aimed at promoting development in the South in a unilinear fashion and the North was supposed to facilitate the process by providing resources wherever needed. The arguments like the responsibility of the North to facilitate the development in the South arose from 


\section{Shalini Singh - From Global North-South Divide to Sustainability}

colonisation, economic exploitation in the past, the need for world peace through global prosperity etc. were popular in academic discourse (Amuzegar, 1976). However, research highlighted the economic benefits of providing development aid as well (Independent Commission on International Development Issues, 1980).

\section{Towards the Sustainability Framework}

The Sustainability Framework for International Development favours policies with a balance among economy, society and environment. It implies that economic growth should not only sustain itself cost-effectively in the long run, but should also be socially and environmentally viable (World Bank Group \& IMF, 2008; OECD, 2012). The benefits of development should be fairly7 distributed across the society and environmental challenges should be addressed while striving for profits (World Bank Group \& IMF, 2008; OECD, 2012).

Different aspects of this framework came gradually on the global agenda. However, the discussion regarding the same was rooted in the OECD since its inception. Promoting sustainable economic growth is the first objective of the OECD Convention, 1960 (OECD, 1960). The official policy of the OECD led by economic experts was to promote economic growth without limits but within the OECD, a factions soon came up with arguments against the model by the late 1960s (Schmelzer, 2016). This faction emphasised the absurdity of unlimited quantitative growth and its unintended consequences in relation to environment and society (Schmelzer, 2016). The faction established the Club of Rome in 1968 and its report, Limits to Growth (1972) stirred up the debate that was already going on in the civil society and various national and international policy circles (Meadows et al., 1972; Schmelzer, 2016). Even though the OECD resources were used to build up and promote the debate, the OECD officially announced its preference for unlimited economic growth, capable of addressing environmental and social problems, in 1973 due to strong opposition by OECD economists, member countries, changing international milieu and the need for growth of the OECD as an institution (Schmelzer, 2016). In 1979, the approach in favour of limited growth was completely rejected by the OECD on paper 
(Schmelzer, 2016; OECD, 1979). Despite this, the Brundtland Commission Report was released in 1987. As the OECD (in policy recommendations) and the WB (in SAPs) adopted a cautious approach favouring harmless economic growth in the 1980s and 90s (Park, 2007; OECD, 2008), the mainstream policy on international development started to change gradually.

\section{Sustainable Growth and International Development}

Through the Club of Rome and the Brundtland Commission reports, the notion of sustainable economic growth strengthened on the global policy agenda. While the North argued for balanced development, the South demanded resources from the North to do so (Thérian, 1999). Development assistance for balanced growth came as a solution (Thérian, 1999). In 1992, the Earth Summit raised Sustainability on the global policy agenda followed by the Copenhagen Declaration (1995) which stated that economic, social and environmental issues for development are equally important and one cannot be addressed at the cost of others (UNESCO, 2014d). The IDGs (1996) proposed by the OECD included economic, social and environmental aspects of development (OECD, 1996). The WB declared them as the monitoring Framework for International Development in 1997 (Bradford, 2002; Hulme, 2009). Despite resistance from the UN, the OECD took control of the policy convergence process, and decided what to include and exclude from the various negotiations going on at the UN platform (Hulme, 2009). While the UN policy favoured a more rights-based idealistic approach, the OECD focussed upon "the politics of what works," thus increasing and using foreign aid in the most effective way (Hulme, 2009). The UN tried to promote all-inclusive idealistic goals but affirmed the IDGs in 2001 amid much resentment from funders, lobbyists and beneficiaries (Hulme, 2009). States thus adopted a reformulated version of the OECD policy as MDGs at the UN platform in 2001, backed by the WB/IMF (Hulme, 2009).

In 2008, the WB/IMF used the financial crisis as an opportunity to introduce Sustainability as the core value for the policy on International Development (World Bank Group \& IMF, 2008). The OECD agenda was now communicated to the South (where development policies were 


\section{Shalini Singh - From Global North-South Divide to Sustainability}

implemented) through the WB/IMF. The OECD had limited engagement outside member countries and the WB/IMF were the perfect actors to set the tone for policy change. Two years later, the UN announced to start negotiations about the new development policy in 2010 (UN, 2010).

The year 2011 became the year of big changes. The aftermaths of the financial crisis were now understood by the common taxpayer and voter while refugee crisis was visible enough to influence the public opinion. This provided another window of opportunity to introduce major policy changes. While the UN prepared for policy 'formulation' through public discussions, meetings, summits, opinion polls, etc.; detailed OECD and EU (major aiddonor) policies on development were announced (European Commission, 2011; OECD, 2011b). The OECD further used this opportunity to make the policy formulation transnational by including stakeholders from market and civil society in direct decision-making (OECD, 2011a).

In 2012, along with other reasons like demographic challenges, redistribution of poverty and affluence, immigration etc., the OECD used the aftermaths of the financial crisis to replace the North-South Framework with the Sustainability Framework (OECD, 2012). UN followed and took the opportunity to announce its development policy. (Not) surprisingly, the UN policy which was claimed to be a result of the so called global negotiations, consultations, voting, bargaining, expert analysis and the like, engaging as many stakeholders as possible (UN, 2012), was not different from the OECD policy. Between 2013 and 2014, the UN tried to facilitate consensus for the policy; in 2015 it was adopted and backed by funding; and finally, in 2016, the WB/IMF came up with indicators to measure and control the outcomes of policy implementation (UN, 2013; 2015a; World Bank Group \& IMF, 2016).

Thus, the idea of sustainable growth was pushed forward by the OECD officially and unofficially gradually while other IOs chose to bandwagon. The entire world became developing once development was redefined in terms of Sustainability (World Bank Group \& IMF, 2016). The division between the North and the South was dropped and the only relevant categorisation for countries remained their income (World Bank Group \& IMF, 2016). The idea of sustainable economic growth thus became the core value for the policy on International Development. However, Sustainability 
Framework is not limited to sustainable economic growth. Mobilizing resources and evaluating the impact of development are two other crucial and intertwined components of this Framework.

\section{Resource Mobilization and Impact Evaluation}

The OECD is working with measurement of aid effectiveness since its inception, showing special interest in increasing the amount of aid for development provided by member countries (Hynes \& Scott, 2013; OECD, 1962, 2013). In 1969, OECD introduced the term Official Development Assistance (ODA) to measure aid which later became the consolidated channel for development financing (Hynes \& Scott, 2013). Questions regarding efficacy of aid and evaluation of aid initiatives were discussed by a special group for evaluation of aid initiatives in several OECD seminars backed by the Nordic Countries, Netherlands and Germany in the 1970s (Hynes \& Scott, 2013; OECD, 2013). Since 1983, WB/IMF, UN Development Program and regional development banks cooperated with the group (Hynes \& Scott, 2013; OECD, 2013). However, the risk of reduction in aid as an unintended consequence of measurement kept the provision out of the International Development policy for decades (Hynes \& Scott, 2013; OECD, 2013).

As the fear of donors regarding loss of allies faded away with the end of the Cold War, they started providing conditional aid (Dunning, 2004). In 1996, the OECD proposed twelve indicators followed by the facilitation of negotiations for aid effectiveness and for developing guidelines regarding the same (OECD, 1996). After the MDGs were adopted, the OECD developed further guidelines for systematic financing of development and impact measurement. MDG 8 aimed to develop a Global Partnership for Development. At Monterrey (2002), the existing hierarchical and unequal donor (North) - recipient (South) relationship changed formally to an equal partnership, implying that the South should take responsibility for its own development, mobilise its own funds before asking for aid, and show accountability for spending the development assistance it received (UN, 2003). The North promised to provide resources to bridge the gap between 
the funding required and available in the South for achieving the MDGs (UN, 2003).

The Paris Declaration (2005) established a monitoring system to assess progress in achieving MDGs and listed implementation measures for ensuring aid effectiveness (OECD, 2008; UN 2009). In 2008, an implementation plan (Accra Agenda for Action) and a conference on development financing followed at Doha (OECD, 2008). The economic crisis was used as a window of opportunity once again since the policy on aid effectiveness developed over decades. In 2010, the OECD proposed norms for evaluation of aid effectiveness which were followed by most DAC member countries thereafter9 (OECD, 2013).

Based on the norms, a Global Partnership for Effective Development Cooperation was established in 2011 to implement the change from aid effectiveness to development effectiveness (OECD, 2011a). The partner countries (not aid-recipients) agreed to evaluate their own initiatives in terms of the contribution of each initiative to achieve the MDGs (and not for a certain amount of aid) (OECD, 2011a; OECD, 2013). The third conference on development financing in 2015 laid down guidelines for implementation (UN, 2015b). Notably, it took about half a century to formulate the policy on aid effectiveness and integrate it with the policy on International Development due to the risks involved (OECD, 2013). Measurement of aid/development effectiveness was therefore, not a new policy which emerged due to the economic crisis or changes that preceded its launch. The change in policy framework was therefore an outcome of a collaborated effort of IOs in 2016.

\section{The Role of IOs}

The funding by members and the potential to influence policies through its policy expertise makes the OECD the most powerful organisation and leader in policy change through policy formulation, at least in the context of International Development.

The WB/IMF focused on monitoring and evaluation of development against MDGs in the South. They invest in policy research and expertise and provide conditional development loans, training and policy 
recommendations to low and middle-income countries (outside Europe). The WB/IMF therefore secure strong intervention in the policies of these countries (Zapp, 2017; Singh, 2018).

The UN claimed the origins of sustainability policy in the Earth Summit (1992) and its development through various UN conferences and events that included all countries and relevant stakeholders across the globe (UNESCO, 2014d). However, sources reveal that the UN claim was distorted, and the change was pushed forward by the OECD followed by the WB/IMF. The UN and its supporting agencies are highly dependent on funding which hinders their ability to push for independent policy changes, but they offer the biggest platform for bargain and negotiations to low and middle-income countries (outside Europe). Equal voting rights of each state in the UN General Assembly despite inequality among them in international political arena, popular consultations, idealistic propaganda for social change, outreach activities to reach all kinds of stakeholders and the like, make the UN and its agencies perfect platforms for gaining legitimacy, marketing, acceptance and implementation of policies with least resistance (and thus less costs). The claims regarding sustainability policy by the UN therefore, obscure the OECD agenda for sustainable economic growth.

\section{Policies on Education for Development}

The current Education for Development policy is embedded in the policy on International Development and therefore reflects the above-mentioned changes (Singh, 2018). Manifested as SDG 4, it aims to: "Ensure inclusive and equitable quality education and promote lifelong learning opportunities for all" (UN, 2015a).

Even though the UN and its supporting agencies were active in the field since the 1940s, Education for Development came in focus primarily after the Sputnik Shock10 (Baten, 2016). During the cold war, the US and the former USSR used education to increase and maintain their spheres of influence in former colonies (Singh, 2018).

The WB has been one of the most influential international actors in the area through funding 11 , production, management and transmission of knowledge (Zapp, 2017; Singh, 2018). Thus, the aid-dependent policy in the 
South has primarily been led by the WB and not the UN (as depicted in the MDGs). In the North, Development Education has been used to convince the taxpayers about the need for development in the South and to motivate them for financial and non-financial contribution (Singh, 2018).

Between the 1960s and the early-1980s, the WB's policy focussed on funding infrastructural projects for secondary and post-secondary vocational education to promote industrialisation that complemented economic growth and nurtured cold war inspirations in the West (Psacharopoulos, 2006; World Bank Group, 2011; Heyneman, 2012; Mundy \& Verger, 2015). During the 1970s and early 1980s, research and reorganisation of the WB staff changed its approach in favour of public spending on primary education and gender parity, leaving other sectors of education to the market (Psacharopoulos, 2006; Heyneman, 2012; Mundy \& Verger, 2015). According to the WB, spending on primary education and gender parity yielded maximum rate of return (Heyneman, 2012). When crisis-ridden countries from the South approached the WB for loans in mid-1980s, its SAPs led to a remarkable decline in access to education among rural populations of these countries (UNICEF, 1987 in Heyneman, 2012). In answer to the consequent growing resentment, the WB pushed forward its sector-specific policy in education based on rate of return (Psacharopoulos, 2006). In early 1990s, more research and staff reorganisation in the WB strengthened its claims but by the end of the decade, a counter-trend started (Heyneman, 2012). As fast-growing industrial countries took loans from the WB and implemented SAPs, outcomes for education proved disastrous because of contextual differences (Heyneman, 2012). The WB was forced to reconsider its stand, drop its sector-specific (basic education) policy and move to post-basic (integrated education) policy (Heyneman, 2012).

WB was not the only IO to change its approach towards Education for Development. The UN and its supporting agencies also changed their policy, but for different reasons. Since the late 1940s, the UN and its supporting agencies like the UNESCO and the UNICEF organised several initiatives for promoting different aspects of education, introduced policy variables like Lifelong Education and promoted an integrated approach towards education (rather than sector-specific approach) (Faure et al., 1972; Jones \& Coleman, 2005; Elfert, 2016; Ehlers, 2019; UNESCO, n.d.). The UNESCO, which 
specifically dealt with Education for Development, was facing competition from the OECD in the global North in the 1980s (Ehlers, 2019). The US, Singapore and the UK chose to engage with the OECD in 1984-85 and withdrew their financial support from the UNESCO (Ehlers, 2019). Consequently, the UNESCO was forced to cut down its activities (Jones \& Coleman, 2005).

Since 1989, the UN platform was used for a series of conferences in different policy areas (UN, 2007). The WB, which was facing much criticism because of the SAPs, co-organised the EFA Conference (1990) with four UN agencies as a counter-measure (Joint Declaration, 1990). In 2000, six EFA goals with an integrated approach towards education in all sectors were adopted. Despite this, the WB's sector-specific policy found place in the MDGs and most EFA goals were left for private action (Faul, 2014; Singh, 2018). While Education for Development policy for the South became limited to sector-specific policy, education in the North prepared for knowledge economy through lifelong learning reforms and integrated qualification frameworks.

To streamline the agenda further, the WB initiated a Fast Track Initiative on EFA (2002) (Global Partnership for Education, n.d.). Despite EFA in its name, the initiative promoted the sector-specific policy of the WB (Global Partnership for Education, 2013, n.d.; UNESCO, 2015; World Bank, n.d.). In 2005, educational aid started being channelled through it (Global Partnership for Education, n.d.) corresponding to the WB's policy.

While poverty led the MDG agenda due to pressure from civil society (Hulme, 2009), the policy on sustainable development developed as an undercurrent. In 2002, the decade 2005-14 was declared as the UN Decade on Education for Sustainable Development to create awareness about Sustainability (UN, 2015a). When the economic crisis came in 2008, resentment against the existing education policy grew. Countries in the South argued that policy implementation was difficult since other educational needs were addressed inadequately (Singh, 2018). Their situation in relation to primary education and gender parity had improved, their dependence on the WB had declined, and they could perceive the challenges of knowledge economy (Rosling, 2018; Singh, 2018). 
Since education policy was embedded in International Development policy, a clear education policy was announced by the WB in 2011 (World Bank Group, 2011), only after the International Development policy took shape. The economic crisis (2008) and the refugee crisis (2011) were thus used as windows of opportunity because the announced education policy was built upon the WB strategy of 2005 (World Bank Group, 2005) prepared before the crisis.

The UN Decade of Education for Sustainable Development (DESD) was divided into two phases: 2005-08 and 2009-14 (UNESCO, 2014d). During the first phase, the idea of Sustainability was promoted through education whereas during the second phase, policy formulation regarding Sustainability began (UNESCO, 2014d). This coincides with the interpretation of development in terms of Sustainability by the WB/IMF (mentioned earlier).

The WB policy to "Invest early. Invest Smartly. Invest for All" portrayed education as an investment rather than a cost (World Bank Group, 2011). The target group of the policy expanded from children and females for primary education in the global South to all individuals across the globe (World Bank Group, 2011). The approach changed from teaching (education) to learning (World Bank Group, 2011). Reflecting the change in the policy on International Development, the EFA-Fast Track initiative was renamed as the Global Partnership for Education, included more stakeholders, and made the South responsible as partner (taking initiatives) rather than aid-recipient (following directions from donors) (World Bank Group, 2011). Focus on learning, measurement, Sustainability and employability; treating education as an investment rather than a cost; mobilisation of non-public resources; integrated rather than sector-wide approach towards education, were all characteristics of education policies in the North. The aid recipient countries were now free to follow the same, despite the aid they received. Education for Development policy in the North and the South converged after decades.

The UNESCO strategy on education, the results of Education for All Steering Committee, and the Muscat Agreement which claimed to be independent reiterated the goals put forth by the OECD, the WB/IMF and the EU, just like in case of International Development (UNESCO, 2014a; 
UNESCO, 2014b; UNESCO 2014c; UNESCO, 2014d; Singh, 2018). The UNESCO indicated the need to adapt its policies in line with the international agenda for development and also released a timeline to show how it pushed sustainability on the global agenda (UNESCO, 2014c). Interestingly, no references to outside influences or linkages with the OECD, or the WB/IMF were made, creating the illusion that the UNESCO steered the policy on Education for Development.

In 2015, the UNESCO criticised MDGs, advocated policy change in favour of an integrated approach for all learners, and facilitated the Incheon Declaration to formulate SDG 4, a fabricated version of the WB policy (World Bank Group, 2011; UNESCO, 2015; UNESCO et al., 2015). Later in 2015, this policy was adopted once again as Education for Development policy but this time, without any resistance or parallel claims from the UN or any of its specialised agencies. The change in policy was marketed and legitimised at the UN platform by 2015 since all documents and declarations by the UNESCO reiterated the agenda already put forth in the documents by the OECD and the WB/IMF but obscured their involvement.

\section{Discussion}

Change in Policy Framework from Global North-South Divide to Sustainability was led by the OECD, supported and implemented in low and middle-income (non-OECD) countries by the WB/IMF (and the ILO (Singh \& Ehlers, 2020)), and marketed and legitimised by the UN and its supporting agencies. It was marked by the move from competition (before 1990s) to collaboration (since 1990s) among IOs. These IOs have risen beyond state control (reducing the role of state) through formulation (using expertise, funding, data, research, etc.), regulation (using guidelines, research etc.), and control (using comparison, evaluation etc. through for instance, indicators) of transnational policies. Such consolidated policies based on comparative advantage of these IOs with reduced resource wastage (due to alternative and conflicting policies), better expertise and procedures, long-term considerations, and data-based informed policy choices are beyond the capability of individual states. 


\section{Shalini Singh - From Global North-South Divide to Sustainability}

Further, these organisations have resorted to transparency and fairness (according to certain rules they have laid down and agreed upon by themselves) to gain legitimacy and have pooled the resources like funding and expertise to ensure efficiency and optimum utilisation of resources. States on the contrary, are marred by national, sub-national political constraints (sometimes resulting in quite inefficient solutions) and thereby, bank upon authority which could be undermined due to transparency.

However, increasingly converged, integrated, aligned and harmonised policies consolidated into a policy mammoth with many complicated interconnections and linkagesmake policy diversion difficult due to path dependency, leading to TINA (There is No Alternative) situations, even if policies result in undesired outcomes. There is no specific checklist to ensure that all externalities are considered while projecting outcomes, and that the policy choices will not lead to undesired outcomes.

Since 2011, the OECD-led move from international (state-predominated, hierarchical) to transnational (non-hierarchical, partner-led negotiations among states, market and civil society actors depending upon their influence and relevance of issues) policy formulation has resulted in inclusive, adaptable and flexible policies representing stakeholder interests that remained (un)represented by the state. Such stakeholders are more likely to cooperate in policy implementation (as compared to those who are not engaged at all) maintain local pressure, keep a check on policy implementation by the state, and collaborate transnationally if the state refrains from supporting them. This has however led to the weakening of state control (not necessarily good or bad) making diversion from agreed policies difficult for the state in the name of non-cooperating stakeholders, even though the policies are not contextually suitable for certain stakeholders in the state.

The shift from cost-based to investment-based approach leading to further streamlining of policies, especially in terms of measurable outcomes along certain indicators based on political (rather than scientific) considerations has changed the way policies are conceived, designed and evaluated. Stakeholders unable to define their outcomes as sustainable will be excluded from the mainstream process of development. 
In relation to education policies, outcomes are prioritised against the method and process of education. This has led to the widening of educational focus from enrolments and gender parity in primary education to outcome-oriented education. This does not mean that education policies will be funded only if they lead to employability but they should rather be clever arguments in favour of promoting sustainability in any form (for instance, building of social capital to support peace and therefore economic growth). However, aspects of education focussing on long-term humanistic changes which are difficult to quantify or could not be visibly aligned with sustainability might even be ignored despite their relevance.

The change from policy based on exclusion (of sectors that give less returns on investment) to inclusion (for everyone, everywhere) allows low and middle-income countries to spend on areas in education relevant for their contexts. With the freedom to prioritise aspects of education according to contextual needs, low and middle-income countries are free to compete in the knowledge-economy competition. This might increase the global competition in knowledge but at the same time, can provide opportunities to new competitors (low and middle income states and non-state actors) for participation.

Redefining Development in terms of Sustainability led to the irrelevance of the North-South Divide and developed-developing conceptual constructs. In the Sustainability Framework, no state can claim to be completely sustainable in all aspects and therefore, all states are developing, irrespective of their location, income or power. The developed-developing categorisation among states was replaced by income-based categorisation by the WB/IMF. This seems promising as it is subject to changes corresponding with the rise and fall in the income of states, less stereotypical (as compared to the location in a certain part of the globe) and more competitive (for development assistance as well as market investments). Unequal donor (developed North) and recipient (developing South) relationship is replaced by equal relationship among development partners striving for sustainable development. Further, assistance to a certain part of the world would no more be justified in favour of development since it is now an objective that every country strives for. 


\section{Conclusion}

The increasing economic-orientation in policies is a result of the OECD-led shift in policy framework for development in favour of sustainable economic growth (not sustainable development). This has been reflected in different policy areas including education. Streamlining policies in favour of economic-orientation and evaluation in terms of optimum utilisation of available resources has been systematically done by the OECD, the WB/IMF and the UN along with its supporting agencies between 1990 and 2015. During the process, these organisations have changed from competitors to collaborators working coherently, beyond state control and capabilities. Policies have become increasingly converged, integrated, aligned, and harmonised into a huge policy mammoth by these organisations. Miscalculations or undesired outcomes in one policy area therefore are bound to have far-reaching consequences for other policy areas irrespective of direct policy linkages among them. Thus, consequences of continuity and changes need to be calculated through maximum possible objective research and informed policy choices (unlike environmental challenges to economic growth that took almost half a century to be addressed). The changes however offer possibilities for clever stakeholders who could manage to highlight the relationship between their stakes and the OECD-led sustainable economic growth agenda.

\section{Notes}

1 The author is thankful to Dr. Paed. Søren Ehlers, Dr. Alexandra Ioannidou, Dr. Anke Grotlüschen and Dr. Klaus Buddeberg for their inputs in writing this article.

2 Due to the influence of the EU in Europe

3 See Section 5: Policies on Education for Development.

4 See Section 4: Towards the Sustainability Framework.

5 A contextually defined policy term which might have different meanings in different contexts. 6 See Section 4: Towards the Sustainability Framework.

7 The definition of fairness could be contextual.

8 The faction was led by the OECD's first head Thorkil Kristensen (an economist) and Alexander King (Science Director) and was primarily rooted in Science and Technology.

9 The norms were developed by Denmark and Australia in initial phases.

10 A major event during the Cold War where former USSR got technological advantage over the West due to investments in education. 
11 The World Bank is the largest funding international organization in education for development (Zapp, 2017).

\section{References}

Amuzegar, J. (1976). The North-South Dialogue: From Conflict to Compromise. Foreign Affairs 54(3), April, 547-562. http://doi.org/10.2307/20039593

Baten, J. (Ed.) (2016). A History of the Global Economy: From 1500 to the Present. Cambridge University Press.

Björkdahl, A. (2002). Norms in International Relations: Some Conceptual and Methodological Reflections. Cambridge Review of International Affairs 15(1), 9-23. http://doi.org/10.1080/09557570220126216 Bradford, C. (2002). Towards 2015: from Consensus Formation to Implementation of the MDGs - The Historical Background, 19902002. Mimeo. The Brookings Institute.

Cambridge Dictionary (n.d.). Framework. Cambridge Dictionary website: https://dictionary.cambridge.org/dictionary/english/framework

Meadows, D.H., Meadows, D.L., Randers, J \& Behrens III, W.W. (1972). Limits to Growth. A Report for the Club of Rome Project on the Predicament of Mankind. A Potomac Associates Book.

Dunning, T. (2004). Conditioning the Effects of Aid: Cold War Politics, Donor Credibility, and Democracy in Africa. International Organization (58), Spring, 409-423. http://doi.org/10.1017/S0020818304582073

Ehlers S. (2019). The rise of a learning regime in Europe. Transnational policy terms mapped and discussed. In T. Fristrup (Ed.), Socially Engaged Practices in Museums and Archives (pp. 17-68).

Fornvårdaren 38. Jamtli Förlag.

Ehrlich, T. (1980). The North-South Dialogue. Articles by Maurer Faculty, 1818, 24-37.

Elfert, M. (2016). The utopia of lifelong learning: an intellectual history of UNESCO's humanistic approach to education, 1945-2015. $\mathrm{PhD}$ Thesis. University of British Columbia.

European Commission (2011). Increasing the impact of EU Development Policy: an Agenda for Change. Communication from the Commission 
to the European Parliament, the Council, the European Economic and Social Committee and the Committee of the Regions, COM (2011) 627 final, 13.10.2011, Brussels.

Faure, E., Herrera, F., Kaddora, A.R., Lopes, H., Petrovsky, A.V, Rahnema, M. \& Ward, F.C. (1972). Learning to be. The World of Education today and tomorrow. UNESCO.

Faul, M. V. (2014). Future-perfect/present-imperfect: Contemporary global constraints on the implementation of a post-2015 education agenda. International Journal of Educational Development, 39, 12-22. http://doi.org/10.1016/j.ijedudev.2014.07.011

Global Partnership for Education (2013). Strategic Plan 2012-2015. Global Partnership for Education.

Global Partnership for Education. (n.d.). Timeline. Global Partnership for

Education website: https://www.globalpartnership.org

Haq, M. ul. (1976). The Poverty Curtain: Choices for the Third World.

Columbia University Press.

Heyneman, S.P. (2012). When Models Become Monopolies: The Making of Education Policy at the World Bank. In C.S. Collins \& A.W. Wiseman (Eds.), Education Strategy in the Developing World:

Revising the World Bank's Education Policy (pp. 43-62). Emerald. Hulme, D. (2009). The Millennium Development Goals (MDGs): A Short History of the World's Biggest Promise. BWPI Working Paper 100, University of Manchester.

Hynes, W., \& Scott, S. (2013). The Evolution of Official Development

Assistance: Achievements, Criticisms and a Way Forward. OECD

Development Co-operation Working Papers, No. 12. OECD

Publishing.

ILO (n.d.). Education Sector. ILO website:

https://www.ilo.org/global/industries-and-sectors/education/lang-en/index.htm

Independent Commission on International Development Issues (1980).

North-South: A Programme for Survival (1980). The Report of the Independent Commission on International Development Issues under the Chairmanship of Willy Brandt. Pan World Affairs. MIT Press. 
Joint Declaration (1990). World Declaration on Education for All, Jomtien, Thailand (1990), 5-9.03.90.

http://bice.org/app/uploads/2014/10/unesco_world_declaration_on_ed ucation_for_all_jomtien_thailand.pdf

Jones, P. W. \& Coleman, D. (2005). The United Nations and education: multilateralism, development, and globalisation. Routledge Falmer.

Mundy, K., \& Verger, A. (2015). The World Bank and the global governance of education in a changing world order. International Journal of Educational Development 40, 9-18.

http://doi.org/10.1016/j.ijedudev.2014.11.021

OECD (1960). Convention on the Organisation for Economic Co-operation and Development. 14.12.1960. OECD.

OECD (1962). DAC Development Co-operation Report. OECD.

OECD (1979). Facing the Future. Mastering the Probable and Managing the Unpredictable. Interfutures. OECD.

OECD (1996). Shaping the 21 st Century: The Contribution of Development Co-operation. OECD.

OECD (2008). The Paris Declaration on Aid Effectiveness and the Accra Agenda for Action. Third High Level Forum on Aid Effectiveness, Accra (Ghana) 04.09.08.

OECD (2011a). Busan Partnership for Effective Development Co-operation. Fourth High Level Forum on Aid Effectiveness, Busan, Republic of Korea, 29.11-01.12.11.

OECD (2011b). OECD 50th Anniversary Vision Statement. OECD Strategy on Development. Meeting of the OECD Council at Ministerial Level, Paris, 25-26.05.11, C/MIN (2011) 6. OECD.

OECD (2012). OECD Strategy on Development. OECD.

OECD (2013). The DAC Network on Development Evaluation - 30 years of strengthening learning in development. OECD.

OECD, World Bank \& ILO (2016). Enhancing Employability. Report prepared for the G20 Employment Working Group with inputs from the International Monetary Fund.

Park, S. (2007). The World Bank Group: Championing Sustainable Development Norms? Global Governance 13(4), 535-556. 
Psacharopoulos, G. (2006). World Bank policy on education: A personal account. International Journal of Educational Development 26(3), 329-338. http://doi.org/10.1016/j.ijedudev.2005.09.001

Rosling, H., Rönnlund, A.R., \& Rosling, O. (2018). Factfulness. Flatiron Books.

Sabatier, P. A. (Ed.) (2007). Theories of the Policy Process. Westview Press.

Schmelzer, M. (2016). The Hegemony of Growth. The OECD and the making of the economic growth paradigm. Cambridge University Press.

Singh, S. (2018). Development Education, International Development and International Relations: Comparative Study of Northern and Southern Perspectives. PhD Thesis. New Delhi: Jawaharlal Nehru University. Singh, S. \& Ehlers, S. (2019). Recognition of Prior Learning: Policy Analysis from Denmark and India. Studies in Adult Education and Learning 25(1), 69-87.

Singh, S. \& Ehlers, S. (2020). Employability as a Global Norm. Comparing Transnational Employability Policies of OECD, ILO, World Bank and UNESCO. In R. Egetenmeyer \& V. Boffo (Eds.). International and Comparative Studies in Adult and Continuing Education. Florence: Firenze University Press. Under publication.

Thérien, J. (1999). Beyond the North-South Divide: The Two Tales of

World Poverty. Third World Quarterly, 20(4), August, 732-742.

http://doi.org/10.1080/01436599913523

UN (2003). Monterrey Consensus of the International Conference on

Financing for Development. The final text of agreements and commitments adopted at the International Conference on Financing for Development, Monterrey, Mexico, 18-22.03.02, UNDESA. United Nations.

UN (2007). The United Nations Development Agenda: Development for All.

Goals, Commitments and strategies agreed at the United Nations World Conferences and Summits since 1990. Department of Economic and Social Affairs, June 2007. United Nations.

UN (2009). Doha Declaration on Financing for Development: Outcome Document of the Follow-up International Conference on Financing for Development to Review the Implementation of the Monterrey 
Consensus. The final text of agreements and commitments adopted at the Follow-up International Conference on Financing for Development to Review the Implementation of the Monterrey Consensus, Doha, Qatar, 29.11-02.12.08, Financing for Development Office, UNDESA. United Nations.

UN (2010). Keeping the promise: united to achieve the Millennium

Development Goals. Resolution adopted by the General Assembly,

Sixty-fifth session, Agenda items 13 and 115, A/RES/65/1, 19.10.10,

United Nations General Assembly. United Nations.

UN (2012). The United Nations Development Strategy Beyond 2015.

Committee for Development Policy, Economic and Social Affairs, Policy Note. United Nations.

UN (2013). A New Global Partnership: Eradicate Poverty and Transform

Economies Through Sustainable Development. The Report of the

High-Level Panel of Eminent Persons on the Post-2015 Development Agenda. United Nations.

UN (2015a). Transforming Our World: The 2030 Agenda for Sustainable

Development, A/RES/70/1. United Nations.

UN (2015b). Addis Ababa Action Agenda of the Third International

Conference on Financing for Development (Addis Ababa Action Agenda). The final text of the outcome document adopted at the Third International Conference on Financing for Development (Addis Ababa, Ethiopia, 13-16.07.15) and endorsed by the General Assembly in its resolution 69/313 of 27.07.15, UNDESA. United Nations.

UNESCO (2014a). Medium Term Strategy 2014-2021.37 C/4. UNESCO.

UNESCO (2014b). 2014 Global Education for All Final Statement. The Muscat Agreement. UNESCO, Oman 12-14 May 2014.

UNESCO (2014c). UNESCO Education Strategy 2014-2020. UNESCO. UNESCO (2014d). Shaping the Future We Want. UN Decade of Education for Sustainable Development (2005-2014). Final Report, DESD Monitoring and Evaluation. UNESCO.

UNESCO (2015). Education For All 2000-2015: Achievements and Challenges. Education for All Global Monitoring Report 2015. UNESCO. 
102 Shalini Singh - From Global North-South Divide to Sustainability

UNESCO (n.d.). History of the Education Sector. UNESCO

https://en.unesco.org/themes/education/about-us/history

UNESCO, UNICEF, World Bank Group, UNPF, UNDP, UN Women, \& UNHCR (2015). Education 2030. Incheon Declaration. Towards inclusive and equitable quality education and lifelong learning for all. 19-22.05.15, Incheon, Republic of Korea. UNESCO.

Wilson, C.A. (2000). Policy Regimes and Policy Change. Journal of Public Policy 20(3), 247-274. http://doi.org/10.1017/S0143814X00000842

World Bank (n.d.). The Global Partnership for Education and the World Bank Group: The Facts. World Bank. https://www.worldbank.org/ World Bank Group (2005). Education Sector Strategy Update: Achieving Education for All, Broadening Our Perspective, Maximizing Our Effectiveness. Final draft paper. World Bank.

World Bank Group (2011). Learning for all: Investing in people's knowledge and skills to promote development. The World Bank.

World Bank Group \& IMF (2008). Global Monitoring Report, 2008: MDGs and the Environment Agenda for Inclusive and Sustainable Development. World Bank.

World Bank Group \& IMF (2016). Development Goals in an Era of Demographic Change. Global Monitoring Report 2015/2016, Washington D.C.: International Bank for Reconstruction and Development. The World Bank.

Zapp, M. (2017). The World Bank and Education: Governing (through) knowledge. International Journal of Educational Development 53, 117. http://doi.org/10.1016/j.ijedudev.2016.11.007

Shalini Singh is a Guest Researcher and Lecturer at the Julius Maxilimians University of Würzburg, Germany.

Email: contactingshalinisingh@gmail.com 


\section{Review}

Odrowąż-Coates, A., \& Goswami, S. (Eds.) (2017). Symbolic violence in socio-educational contexts. A post-colonial critique. Warsaw: Wydawnictwo Akademii Pedagogiki Specjalnej im. Marii Grzegorzewskiej. ISBN 978-8364953-69-9

The book Symbolic violence in socio-educational contexts. A post colonial critique is a joint publication prepared by authors from all around the world: Algeria, Ecuador, India, Italy, Netherlands, Nigeria, Poland, the UK and the USA. It is designed around the broad theme of symbolic violence (e.g., Bourdieu \& Passeron, 1977) and is connected to the idea of post-colonialism (e.g., Grosfoguel, 2008, 2013; Moraña et al., 2008). The discourse in the book encompasses various contexts - starting from the traditionally understood socio-educational context (Part I and II of the book) and meandering through other fields, e.g., language (Part II), art and health (Part IV). Moreover, Part III is devoted to meta-thinking about the theoretical framework of the book. It is a brave and successful attempt to create a common space for multinational and multicultural voices to reflect on a wide variety of deeply humanistic topics.

The critical pedagogy approach inspired the creation of the book and the selection of the content (Odrowąż-Coates \& Goswami, 2017a, p. 7). However, the adjective "critical" might also be applied to this work in another context. The problems and issues raised in the book are critical to 
the contemporary, globalized world dealing with the heritage of Westerncentrism. As mentioned in the Preface, "This collection of essays, (...) point to the very real necessity to humbly ask non-Western peoples, to share their wisdom (...) and for the West to begin to recognize that it is high time we begin looking elsewhere for answers to our most pressing and persistent problems" (Monzó, 2017, p. 10). This sentence reflects the critical need to go beyond the established patterns of thinking to find new solutions to social problems. In my view, the book in itself is an attempt to cross boundaries of many kinds: own thinking, scientific discipline of interest, as well as cultural and national identity - and encourages the reader to do so.

It is crucial to cross the boundary of own thinking in order to be open to experiencing the perspective of others. The book mentions issues that evoke emotions - often stark - and provoke a dialogue with own values. These matters are, for instance, trauma, violence or non-heteronormative sexuality. The design of the book encouraged the openness and freedom of the contributors, showing respect to both their viewpoints and to the fragility of the topics. The reader, following this pattern, is presented with the phenomena without being forced to take anything for granted.

Another boundary that should be crossed while reading the book is that of scientific disciplines. Interdisciplinarity is often considered necessary for the post-colonial framework, which is a basis for this book (e.g., Connell, 2004; Huggan, 2008; Wareing, 2009). Initially, the disciplines covered within might be viewed as discrete (e.g., pedagogy, sociology, art and architecture, medicine, cultural anthropology). However, including these disciplines is both deliberate and relevant. Furthermore, despite the risk of mixing a variety of perspectives, the book does not offer entropy, but logic and order, facilitating the understanding of both the individual parts and the whole material.

However, to fully benefit from this understanding, another boundary - of cultural and national identity - needs to be crossed. The authors are of various nationalities and cultural backgrounds. The themes are concentrated on various cultural contexts. In my view, similarly to developing the theory of mind (e.g., Premack \& Woodruff, 1978; Leslie et al., 2004), in the case of this publication, readers are invited to build a "cultural" theory of mind and 


\section{Nowakowska - Symbolic Violence [Book Review]}

to practice switching one's own perspective to the perspective of people from other cultures.

Crossing boundaries is not the only competence that can be achieved through reading this book. Another one is critical meta-thinking about the presented material. The authors leave space for own afterthought, not providing straightforward solutions to presented matters. Meta-thinking is a complex skill to be learned, however, analyzing this material and coming back to it might help develop this competence, which is crucial in the contemporary world of constant information streaming.

The book might be recommended to all groups of recipients. These can be both specialists already prepared for critical meta-thinking as well as readers who are less adept, but curious and open to novel understandings, gaining multicultural literacy and the experience of crossing boundaries.

\section{References}

Bourdieu, P., Passeron, J. C. (1977). Reproduction in education, culture and society. Sage.

Connell, L. (2004). Post-colonial interdisciplinarity. Critical Survey, 16(2), $1-6$.

Grosfoguel, R. (2008). World-system analysis and postcolonial studies: A call for a dialogue from the 'Coloniality of Power' approach (pp. 94104). In R. Krishnaswamy \& J.C. Hawley (Eds.), The postcolonial and the global. University of Minnesota Press.

Grosfoguel, R. (2013). The structure of knowledge in westernized universities: Epistemic racism/sexism and the four genocides/epistemicides of the long 16th century. Human Architecture: Journal of the Sociology of Self-Knowledge, 11(1), 7390.

Huggan, G. (2008). Interdisciplinary measures: Literature and the future of postcolonial studies. Liverpool University Press.

Leslie, A. M., Friedman, O., German, T. P. (2004). Core mechanisms in 'theory of mind'. Trends in Cognitive Sciences, 8(12), 528-533. http://doi.org/10.1016/j.tics.2004.10.001 
Monzó, L. (2017). Preface. In: A. Odrowąż-Coates, S. Goswami (Eds.) (2017). Symbolic violence in socio-educational contexts. A postcolonial critique (pp. 9-10). Wydawnictwo Akademii Pedagogiki Specjalnej im. Marii Grzegorzewskiej.

Moraña, M., Dussel, E. D., Jáuregui, C. A. (Eds.). (2008). Coloniality at large: Latin America and the postcolonial debate. Duke University Press.

Odrowąż-Coates, A., Goswami, S. (2017a). Foreword by the editors. In: A. Odrowąż-Coates, S. Goswami (Eds.) (2017). Symbolic violence in socio-educational contexts. A post-colonial critique (pp. 7-8).

Wydawnictwo Akademii Pedagogiki Specjalnej im. Marii Grzegorzewskiej.

Odrowąż-Coates, A., Goswami, S. (Eds.) (2017b). Symbolic violence in socio-educational contexts. A post-colonial critique. Wydawnictwo Akademii Pedagogiki Specjalnej im. Marii Grzegorzewskiej.

Premack, D., Woodruff, G. (1978). Does the chimpanzee have a theory of mind? Behavioral and Brain Sciences, 1(4), 515-526. http://doi.org/10.1017/S0140525X00076512

Wareing, S. (2009). Postcolonial discourse as an analytical framework to explore disciplinarity and transdisciplinarity in higher education. Studies in Higher Education, 34(8), 917-928. http://doi.org/10.1080/03075070902929519

Iwona Nowakowska, The Maria Grzegorzewska University insd2@aps.edu.pl 


\section{List of Reviewers}

We would like to thank all our Reviewers during the period of 2019. Their effort and contributions have increased the quality and scientific rigor of the International and Multidisciplinary Journal of Social Sciences.

Yours sincerely,

Tinka Schubert

Editor

Ahmad, Muhammad

Álvarez-Jiménez, Gemma

Amsalu, Tadasse

Anwar, Aftab

Bora, Bani

Bosch, José Luis

Brunet, Ignasi

Burgues de Freitas, Ana

Buslón, Nataly

Cortés, Marta

De Botton, Lena

Fanarraga, Irina

Farooq, Muhammad

Gómez, Carlos

Kröner, Stefanie

Mara, Liviu

Merodio, Guiomar
Mondejar, Eduard

Morlà, Teresa

Peña Axt, Juan Carlos

Pulido, Cristina

Ray, Shovana

Redondo Sama, Gisela

Rehman Khan, Syed Abdul

Rodríguez, Alfonso

Serrano, María Ángeles

Siles, Gregor

Singh, Shalini

Sorrolla, Natxo

Taberner, José

Torras, Elisabeth

Vazquez, José-Luis

Villarejo, Beatriz

Warby, Brian 